\title{
The Occurrence and Impact of Pension Fund
}

\section{Discontinuity}

\author{
Working paper
}

Gosse A.G. Alserda ${ }^{1}$, Onno W. Steenbeek ${ }^{1,2}$ and S.G. (Fieke) van der Lecq ${ }^{3}$

${ }^{1}$ Erasmus School of Economics, Erasmus University Rotterdam

${ }^{2} \mathrm{APG}$ Asset Management

${ }^{3}$ Faculty of Economics and Business Administration, Vrije Universiteit Amsterdam

May 5, 2017

\begin{abstract}
Collective pension arrangements tend to yield higher risk-adjusted pension benefits than individual plans due to intergenerational risk sharing and the lack of annuity conversion risk. These benefits pose the implicit assumption that the pension fund has an infinite horizon, while we observe that many pension funds discontinue. Using case studies of six discontinued pension funds, in combination with a simulation model, this paper analyses the occurrence and impact of pension fund discontinuity. Although discontinuity tends to increase the volatility of pension benefits, median benefits in most institutional settings increase after discontinuing the fund. We find that both the occurrence and impact of discontinuity depends strongly on the institutional setting of the pension fund. Stricter regulations, such as more conservative discount rates, increase the financial stability of the pension fund; however, they may reduce membership support through lower replacement rates. This poses a trade-off in the design of the pension system.
\end{abstract}

*We thank Maurits Aben, Jurre de Haan and Adri van der Wurff for their useful comments and the Dutch pension funds association (Pensioenfederatie) for providing a list of discontinued pension funds 


\section{Introduction}

Several European countries have experienced a decline in the number of pension funds in the past decade. During the period 2005-2015, the number of pension funds declined 60\% in the Netherlands and Denmark, $52 \%$ in the United Kingdom, $33 \%$ in Switzerland, $27 \%$ in Norway, and $4 \%$ in Germany (OECD, 2015). The pension fund decline in these countries is the result of mergers, closures, and liquidations (with a transfer to a different entity) of pension funds. Sometimes, it is in the interest of plan members to discontinue the fund, as continuation may result in lower or more volatile benefits. However, closing the plan may impose risks as well, such as a conversion risk caused by continuation with another pension fund. The discontinuation of a substantial number of pension funds raises the question of whether discontinuity poses a risk to the stakeholders of the pension fund and, in particular, to the members of the pension funds.

A discontinuity event can be a risk to pension fund members because risks that are meant to be shared between generations (intergenerational risk sharing) may all fall upon the last generation present in the pension fund at the moment of discontinuity. When rights are not transferred to a different entity, the last generation will become residual claimants, increasing rather than decreasing the riskiness of their pension benefits. The possibility that an existing pension fund might go into runoff (i.e., closure of the fund to all new contributions, while existing rights remain in the pension fund) may discourage new generations from joining the pension fund, which may trigger a discontinuity event on its own (Beetsma et al., 2012). Please note that when the pension fund discontinues, the pension plan may continue in a different entity, in which case the pension fund will not go into runoff. We take the option of runoff as the default option at a discontinuity event, but we will discuss these alternative options (that give rise to amongst others conversion risk) at a later stage. While a discontinuity event is likely to increase the riskiness of pension benefits, it may also release any potential buffers in the pension fund, which may increase retirement income in the wake of a discontinuity event. Therefore, in this paper we analyse the impact of discontinuity risk, as pension fund discontinuity can have both a positive and negative effect on pension fund members.

Discontinuity events in pension funds can be triggered by financial and social circumstances. When the financial position (i.e., solvency) of a pension fund becomes too weak, financial supervisors or sponsoring employers may force the pension funds to discontinue. Alternatively, when participation is not mandatory, present and/or future members can force the pension fund to discontinue (e.g., by leaving the pension fund) when they lose trust. This can happen when the replacement rate of the pension is lower than promised or when contributions are too high. However, both triggers are strongly linked. Pension funds can improve their financial by cutting pension rights, but this will diminish their social position 
(membership trust), as members will face lower benefits. However, at the same time a poor financial position will also diminish the social position, as members will expect that pensions will not be fully paid in the future. Therefore, both a strong and weak financial position can undermine the social position of the fund. The opposite may also hold, as in situations where sponsors and plan members remain confident, while the fund is underfunded. These situational combinations motivate the case studies that follow.

Discontinuity can be triggered both internally and externally. Internal triggers (e.g., pension cuts) are at the discretion of pension fund boards, while external triggers (e.g., bankruptcy of the sponsoring employer) are not. This creates four different categories of discontinuity triggers. Although discontinuity can have different triggers, the result is the same: the fund ceases to exist. All members become inactive, and no new contributions will enter the pension fund. The existing members will remain in the pension fund, now in runoff, until they die or until their pension rights are transferred (liquidation). As the discontinuity event does not depend on the type of trigger, in this paper we will analyse a single discontinuity event, although the financial and social positions at discontinuity will differ.

Discontinuity risk is strongly linked to the institutional setting of pensions. Institutional factors (e.g., such as regulations of the discount factor for pension liabilities, the cost structure of pensions, legal options to cut pensions, and population characteristics) impact the perceived financial position of the fund, which in turn influences pension fund discontinuity. The extent to which participation in a plan is mandatory also directly effects discontinuity risk in a pension plan, as it determines whether pension plan members can leave when they want to and thereby trigger a discontinuity event. This implies that pension funds with the same asset value and pension liabilities can have different exposures to discontinuity risk, depending on their institutional setting.

This paper relies upon a stream of recent literature analysing discontinuity risk of collective funded pension funds, including: Beetsma and Bovenberg (2009); Bovenberg et al. (2007); Bovenberg and Mehlkopf (2014); Molenaar et al. (2011); and literature discussing intergenerational risk sharing in collective pension funds, including: Bonenkamp and Westerhout (2014); Chen et al. (2016); Cui et al. (2011); Gollier (2008); Ponds and Van Riel (2009); Teulings and De Vries (2006). This paper builds on this literature by explicitly focusing on the occurrence and impact of discontinuity events. We quantify both the occurrence of discontinuity events and their impact on replacement rates. In addition, we analyse the dependency of the institutional setting on the occurrence and impact of pension fund discontinuity events. By using a practical simulation model with a long time period ranging up to 250 years, we can estimate and visualize the effect of discontinuity on a continuously changing population, with multiple generations. In addition, it allows us to assess the effect of a number of properties, (e.g. such as accumulation and contribution, discount rules, cost structures, and life expectancy shocks) on the impact of discontinuity. 
After discussing the theory of discontinuity risk in pension funds, we will describe six recent cases of pension funds in the Netherlands that have faced a discontinuity event. This will give information about the causes of discontinuity and the development of relevant indicators of pension funds in runoff, such as the coverage rate and indexation (i.e., pension funds that have no active members and therefore receive no new contributions). This information is used to calibrate a simulation model that we will use to both simulate the occurrence of discontinuity events and development of pension funds after the event.

This paper shows that discontinuity events, both in practice and in theory, are not as infrequent as intergenerational risk sharing may require (Beetsma et al., 2012). Discontinuity events become relevant when one considers the long horizons that pension funds have. Pension fund boards give various reasons that motivate their decision to discontinue, most often citing high costs per member due to a lack of access to economies of scale. The case study shows that while pension funds choose different ways to continue the pension plan after discontinuation of the fund, the result is not unilaterally bad for the members in all cases. The simulation model also shows that discontinuity can have both positive and negative effects for pension fund members, but the impact depends strongly on the institutional setting of the pension fund and its members.

\section{Theory}

\subsection{Intergenerational risk sharing}

One of the core reasons for collective pension arrangements is the possibility of benefiting from intergenerational risk sharing. Intergenerational risk sharing allows generations that face long term economic downturns to be compensated by generations that face better economic times. In this way all generations face less risk, increasing expected risk-adjusted returns (Bovenberg and Mehlkopf, 2014; Cui et al., 2011; Gollier, 2008). When economic circumstances are good, part of the excess returns are transferred to the future by higher buffers, while in the case of economic downturns, benefits will be reduced less than proportionally by allowing for lower or even negative buffers.

However, for intergenerational risk sharing to work, two requirements have to be met. First, the current generation should believe that future generations will join the system. Without the future generation, any deficit present in the buffers will be fully attributed to the new generation, who may be unwilling to join if they have to make large transfers to older generations (Westerhout, 2011). Second, risks should be shared symmetrically, in two-sided solidarity. Both negative and positive buffers should be shared; otherwise, support for intergenerational risk sharing will soon diminish (Ponds, 2003). This requires both 
commitment and restraint from the current generation, especially in the case of economic prosperity.

\subsection{Discontinuity risk}

Intergenerational risk sharing implicitly assumes that pension funds have an infinite horizon. If a pension fund doesn't have an infinite horizon and ceases to exist at a certain point, the previous generation cannot share the risks with any future generation. If there is no future generation to share risks with, pension fund members will not be willing to make the expected transfers to older generations if the pension fund has a deficit (Westerhout, 2011).

The possibility of a discontinuity event decreases the value of risk sharing for pension funds. In practice, pension funds discontinue on a regular basis (Alserda et al., 2017; Bikker and De Dreu, 2009). For example, over the period 2005-2015, more than half of Dutch, Danish, and British pension funds discontinued (OECD, 2015). It is therefore important to analyse discontinuity of pension funds and its implications for pension fund members.

There are a number of options available for pension plans that discontinue. When rights are not transferred, a pension plan that discontinues goes into runoff. This implies that no new contributions are paid to the pension fund and all active members become inactive. The pension fund continues to exist until the last member dies or the last rights are transferred. A pension fund that goes into runoff is used in the remainder of this paper to simulate the impact of discontinuity, as this is, contrary to the other options, not dependent on any negotiations with external parties.

Pension funds have a number of alternative options when they face discontinuation. One option is to merge with another pension fund, which can be a company pension fund, industry-wide pension fund, or a general pension fund. This will increase the size of the newly formed pension fund, potentially lowering costs in the presence of economies of scale and improving the benefits of risk sharing (when there is no ring fencing, which would otherwise keep risk sharing unchanged).

Another option is to transfer rights to an insurance firm. This will increase the security of pension rights, as insurance firms are not allowed to cut benefits. However, the premium for collective pension insurance contracts usually does not allow for indexation, and this increases the inflation risk for the plan members. When rights are transferred to an insurance company, the total value of the pension's entitlements strongly depends on the interest rate. In a low interest rate environment, this option is very expensive. Thus, the additional security of the insurance company may require a cut in pension entitlements at the transfer moment. 


\subsection{Discontinuity triggers}

There are numerous types of discontinuity triggers. We distinguish four types of triggers: internal and external. Internal triggers originate from within the pension fund itself, while external triggers originate from outside the influence of the pension fund. Both internal and external triggers can be financial and social triggers. Financial triggers are related to the financial position, in particular the solvency, of the pension fund, which will be monitored by financial supervisors, while social triggers are connected to the trust of members and sponsors, including trade unions.

\subsubsection{Internal triggers}

Most papers find that collective pension funds, due to the possibility of intergenerational risk sharing, give higher expected benefits or lower risk (Gollier, 2008; Beetsma and Bovenberg, 2009; Westerhout, 2011). However, if collective pension funds have substantially large negative buffers, individual members may prefer funds with individual accounts, which by definition have no buffers (Teulings and De Vries, 2006; Bovenberg et al., 2007; Beetsma et al., 2012). This implies that when the negative buffer (which lowers expected benefits) is large enough and participation is not mandatory, new members are no longer willing to join the fund and current members apply to leave i.e., the members vote with their feet. The remaining members can no longer share risks with the next generation and become residual claimants. The negative buffer can therefore act as a trigger for a discontinuity event.

Another potential internal trigger for a discontinuity event is the replacement rate. Making use of a survey Binswanger and Schunk (2012), the authors find that members have a minimum level of monthly spending at retirement below which they do not want to fall. These minimum spending levels, denoted in relation to working income (the replacement rate), vary strongly between members and between different income quantiles. However, the authors conclude that the net certainty equivalence value of retirement income should exceed $70 \%$ of net annual working-life income. If the expected replacement ratio decreases below this threshold (e.g., because current retirees have low pensions, or because future pension cuts are expected), plan members may no longer be willing to pay the contributions. Pension funds are thus limited in the amount of pension cuts they can impose that fund members will accept. However, net replacement rates in general exceed gross replacement ratios due to savings, tax brackets, and owneroccupied housing (Brady, 2010). Gross replacement rates may thus be somewhat lower (e.g., than 70\%), depending on the tax system in a specific country (e.g., in countries that have lower taxes for retired individuals).

In the case of a discontinuity event, the last generation present will bear all residual risks ${ }^{1}$, increasing

\footnotetext{
${ }^{1}$ Some risks, like that of setting contributions too low, may disappear, but these are much less in impact.
} 
rather than decreasing the riskiness of pension benefits. Pensions of this generation will depend very strongly on the deficit (downside risk) or surplus (upside risk) of the pension plan at the moment of discontinuity. The very expectation that future generations may be unwilling to participate can therefore make current generations (i.e., younger workers) unwilling to participate, as they fear becoming the residual risk bearers. Discontinuity can become a self-fulfilling prophecy: Once future members believe that it may happen, they will have incentives to trigger it themselves by refusing to join the fund.

\subsubsection{External triggers}

External triggers are factors outside the pension fund that affect pension fund discontinuity. Although the factors may originate from outside the pension fund (e.g., asset return, interest rate, inflation, and changes in life expectancy), they can be mitigated by pension fund management. Applying financial instruments (hedges) can, for example, mitigate the effect of asset return shocks. Without hedging these risks, asset return shocks can decrease assets or increase liabilities, resulting in solvency problems indicated by the coverage rate.

Other external triggers, like changes in life expectancy, can only be hedged at high costs. A change in life expectancy increases the number of years that pension benefits must be paid. This increases pension fund liabilities, again decreasing solvency.

Discontinuity can also be triggered by the population. If it is substantially skewed (e.g., when the population mainly consists of older, retired, members), the pension fund does not fully benefit from the risk-decreasing effect of new contributions. This makes the financial position more volatile and might put constraints on the asset allocation. Both the higher volatility and lower flexibility in the asset allocation makes the pension plan less valuable to the members, making discontinuity more likely. The same is true if the population size decreases (e.g., because the sponsoring company downsizes or disappears, or the industry declines or disappears), which will make the financial position more volatile and increase the effect of fixed costs on pension fund management.

Discontinuity is immediately triggered when the active population disappears in its entirety. This can happen when the company or industry of that pension fund disappears (e.g., by bankruptcy or merger of the company, or development of a new industry that makes the old industry obsolete), or when the company or industry either transfers the pension accumulation to a different provider or discontinues the pension plan. This will make all the active members inactive, effectively putting the pension fund in runoff.

Finally, discontinuity can be triggered by regulatory changes. New regulations can either force a pension 
fund to discontinue or make it practically impossible to continue. Examples include more elaborate reporting standards (e.g., increasing costs per member, especially for smaller funds) and higher board member competence level standards, thus making it more difficult to fill board positions.

\subsection{Modelling discontinuity}

Although there are many triggers that effect discontinuity, it always comes down to one of two types. The first type of trigger is discontinuity due to financial problems. In this case, pension funds become insolvent when deficits (i.e., liabilities surpass assets) become too high. For this reason, financial supervisors or the sponsoring company may force pension funds to discontinue, as contributions to restore the financial position might become too high. The second type of trigger is connected to membership support. If participation is not mandatory, making support from (future) members uncertain, this may lead to the exit of current members or decline of new members, which eventually leads to the discontinuation of the pension fund. Membership support is difficult to measure, but other variables like opt-outs (e.g., number of members who refuse participation) and survey responses can be used to measure it. Relevant causes for declining membership support include expected retirement income (replacement rate) falling below the acceptable minimum; expected income from other plans (e.g., individual pension plans) giving higher expected income; riskiness of retirement income becoming too high (i.e., the chance of falling below the minimum becomes too high); lack of support in the pension fund board; or disagreement with changes in the plan characteristics. These two causes i.e., financial and social causes) represent a trade-off in pension fund management. Applying pension cuts, increasing contributions, and increasing the riskiness of assets improve the (expected) financial position of the pension fund but may lower membership support and therefore increase the probability of social discontinuity. When, for example, the number of members becomes very low, increasing the average cost of running the pension plan, the pension fund can either choose to lower benefits, thus decreasing membership support, or allow the financial position to deteriorate, which might or might not be a problem, depending on the available buffer.

In this paper, we leave the possibility of increasing pension contributions out of the analysis. Depending on local legislation, pension funds in many countries can, or are obliged to, increase contribution levels, which helps solve solvency problems. However, the maximum level of contributions is often limited, and increases in contribution levels will lower membership support. In addition, in many countries the sponsor pays a part of the contributions, increases in the contribution (including repair payments) beyond a certain point will cause difficulties for the sponsor. Contributions in our model can be assumed to be set at the maximum accepted level. Therefore, further increases are not an option in the model. 


\subsection{Institutional setting}

Discontinuity events are highly dependent on the institutional setting of a country. By institutional setting, we refer to regulations, cost structures, population characteristics, and other institutional factors that may influence pension fund performance. Circumstances that in one setting will lead to a discontinuity event may have no effect in another setting. Therefore, it is important to connect the literature of discontinuity risk to the institutional setting.

An important institutional property is the calculation of liabilities, particularly the discount rate used to discount future payouts. Countries like the Netherlands that use a conservative discount factor, will force pension funds to acknowledge relatively high liabilities, which imply a lower coverage rate. Pension funds in countries like the United States that allow for higher discount rates will report lower liabilities and higher coverage rates. This implies that reported solvency may differ from the actual solvency. Two comparable pension funds (equal actual solvency), though in different countries, one can have reported solvency problems and face discontinuity, while the other has no solvency problems at all.

The same holds true for the extent to which pension funds are allowed to run coverage deficiencies. Countries differ in the deficit that pension funds are allowed to run before they have to apply pension cuts. Furthermore, the size of pension cuts differ, as well as the number of years over which the pension cut can be divided. When pension cuts are more likely, members will distrust the plan and become inclined to trigger a discontinuity event. The pace at which pension cuts have to be applied determine which generation is most affected. Fast pension cuts will impact older pension fund members, but slow pension cuts will more strongly impact new and younger fund members. Some pension funds (e.g. in the United States) are not allowed at all to cut pension benefits. These pension funds can continue with large (implicit) deficits, which can make them look closer to a pay-as-you-go plan than a funded plan. And while pension cuts may be legally allowed, the willingness of the population to act against it (e.g., strike) can still make them very difficult to enact.

The distribution of age categories also influences pension fund discontinuity. Age distributions tend to differ across countries (e.g., low birth rates) and industries (e.g., disappearing industries). Pension funds that have relatively many retirees ("sinking giants") become more vulnerable, as these funds will have fewer options available to restore the financial position, and any potential deficit present will tend to magnify for these funds (Frijns, 2010). Therefore pension fund discontinuity becomes more likely.

Another important difference between countries is whether pension fund participation is mandatory. When pension fund participation is mandatory, members cannot trigger a discontinuity event by leaving the pension fund. When participation is quasi-mandatory (i.e., mandatory for employees of a certain 
company or industry), members cannot leave the pension fund easily. If they want to leave the pension fund, they should find another job or motivate social partners or the employer(s) to force a discontinuity event. As leaving the fund becomes more difficult, discontinuity events are less likely to occur. When participation is completely free, members are most likely to leave the pension fund and trigger discontinuity for the pension fund. In these cases, the fund usually has strong DC-elements.

Finally, the first pillar and taxes can be relevant for discontinuity events. Pension fund members in countries that have high base pensions and progressive taxes will be less sensitive to differences in their risk-bearing (e.g., occupational) pension (Alserda et al., 2016). In addition, in some countries taxes and the base pension tend to be adjusted in line with purchasing power developments. When country-wide pension benefits decline (e.g., due to an asset return shock), the government can compensate purchasing power by reducing taxes or by increasing the base pension. In these circumstances, members will be less inclined to leave the pension fund and performance becomes a relative matter: Pension funds are more easily able to cut pension benefits as long as other funds also cut pensions.

Table 1: Institutional setting and pension fund discontinuity

\begin{tabular}{|c|c|c|}
\hline \multirow[t]{2}{*}{ Setting } & \multicolumn{2}{|c|}{ Institutional factor } \\
\hline & High & Low \\
\hline Membership obligation & $\begin{array}{l}\text { More difficult for members } \\
\text { to leave the pension fund, } \\
\text { making discontinuity less likely. }\end{array}$ & $\begin{array}{l}\text { Members can leave when } \\
\text { they have a better alternative. } \\
\text { Discontinuity is more likely. }\end{array}$ \\
\hline $\begin{array}{l}\text { Conservative discount } \\
\text { rate }\end{array}$ & $\begin{array}{l}\text { Low discount rate results in } \\
\text { higher value of liabilities, and } \\
\text { a lower coverage rate. Solvency } \\
\text { problems are more likely. }\end{array}$ & $\begin{array}{l}\text { Solvency problems are less } \\
\text { likely, but members may } \\
\text { distrust the financial position } \\
\text { of the pension fund. }\end{array}$ \\
\hline $\begin{array}{l}\text { Maximum allowed } \\
\text { coverage deficiency }\end{array}$ & $\begin{array}{l}\text { Pension cuts are less likely, } \\
\text { members will be less inclined } \\
\text { to leave the pension fund, } \\
\text { as replacement rates increase. }\end{array}$ & $\begin{array}{l}\text { Pension cuts are more likely, } \\
\text { alternatives, such as an } \\
\text { individual plan, will become } \\
\text { more attractive in the case of } \\
\text { deficits. }\end{array}$ \\
\hline Pace of pension cuts & $\begin{array}{l}\text { Impact on younger members } \\
\text { is relatively lower, so they are } \\
\text { less likely to leave the pension } \\
\text { fund. }\end{array}$ & $\begin{array}{l}\text { Young and new members will } \\
\text { incur more pension cuts, } \\
\text { making them less likely to } \\
\text { continue membership or join. }\end{array}$ \\
\hline Fixed costs & $\begin{array}{l}\text { Pension funds become more } \\
\text { sensitive to population shocks, } \\
\text { discontinuity will become more } \\
\text { likely. }\end{array}$ & $\begin{array}{l}\text { Average costs are more } \\
\text { constant, discontinuity is } \\
\text { less likely. }\end{array}$ \\
\hline Height of base pension & $\begin{array}{l}\text { Volatility and importance } \\
\text { of risk-baring pension decreases, } \\
\text { discontinuity is less likely. }\end{array}$ & $\begin{array}{l}\text { Risk-baring pension is more } \\
\text { important and members will } \\
\text { be sooner inclined to look } \\
\text { for alternatives. }\end{array}$ \\
\hline $\begin{array}{l}\text { Progressivity of income } \\
\text { taxes }\end{array}$ & $\begin{array}{l}\text { Volatility in outcomes are } \\
\text { reduced by income taxes. Lower } \\
\text { volatility reduces discontinuity } \\
\text { events. }\end{array}$ & $\begin{array}{l}\text { Higher volatility for pension } \\
\text { benefits, discontinuity is } \\
\text { more likely. }\end{array}$ \\
\hline
\end{tabular}


The impacts of the most important institutional factors on pension fund discontinuity risk are summarized in Table 1. These factors represent a paradox in pension fund discontinuity. Stricter pension regulations, like more conservative discount factors, smaller allowed deficits, and faster pension cuts, increase the financial stability of pension funds. However, at the same time they tend to stimulate pension fund discontinuity. More conservative discount rates, smaller allowed deficits, and faster pension cuts increase the probability and size of pension cuts, which will lower membership support. Depending on the freedom of pension fund members to leave the fund, this may induce a discontinuity event. These kinds of effects are therefore relevant for pension fund discontinuity. This suggests that a trade-off may exist in pension fund discontinuity. More stricter regulations will make pension funds more robust, but will lead to lower perceived solvency, which might trigger discontinuity.

\section{Case study}

In this section we will analyse six cases of pension funds that faced a discontinuity event. The cases are selected from a list of discontinuity events in the Netherlands presented by the Dutch pension funds association (Pensioenfederatie). Cases are selected in order to represent different types of pension funds that discontinue (i.e., company and industry-wide pension funds) and different reactions to the discontinuity event (i.e., transfer to a company fund, industry-wide fund, general fund, or insurer). Availability of pension fund data and motivation of choices are also factors in case selection.

The six cases that are selected are the industry-wide pension fund for miners (consisting of Algemeen Mijnwerkersfonds van de Steenkolenmijnen en Beamtenfonds voor het Mijnbedrijf), the company fund of Elsevier publishers (Stichting Pensioenfonds Elsevier-Ondernemingen), the industry-wide fund for the plastic and rubber industry (Bpf Kunststof- en Rubberindustrie, KRI), the company fund of telecom provider KPN (OPF KPN), the company fund of RBS bank (RBS NL Pension fund), and the company fund of ING bank (ING Pensioenfonds). The analysis of these case studies is based on the information retrieved from annual reports and press statements. The information therefore presents stated motivations, which can leave out other relevant motivations. So, although these case studies (as summarized in Table 2 give us valuable insight into pension fund discontinuity, we should keep in mind that there might be other motivations for the discontinuations of the discussed pension funds.

The pension funds for miners (AMF and BMF) went into runoff after the closure of the mines in the Netherlands in the 70s. During the next few decades, the pension funds continued to exist without active members while the total number of members decline. By cooperating, they managed to continue their operation, but the declining membership made their pension fund increasingly expensive to operate. The 
lack of active members put more limitations on their asset allocation. It also made the pension funds less attractive to industry-wide funds to merge into, as they would not contribute any future members. Therefore, the choice was made to transfer the pension rights and assets of both funds to the insurance firm Aegon in 2014. Pension rights were incremented upon transfer, but will not be indexed (or cut) in the future (AMF-BFM, 2016).

The company fund of Elsevier choose to discontinue because a decreasing number of employees (members), in combination with more stringent regulations, led to increasing costs. The rights were transferred to PGB, an industry-wide fund. The alternative, transferring rights to an insurance firm, was considered too costly due to the low interest rate in 20152016. The sponsoring company made a one-off payment to get the coverage rate of the liquidated fund equal to the coverage rate of the new fund (PGB) (Stichting Pensioenfonds Elsevier-Ondernemingen, 2015).

KRI, the industry-wide fund for plastic and rubber companies, formerly insured their pension rights with an insurance firm. Due to the low interest rate, the company considered it too expensive to renew the reinsurance contract at the end of 2016 and decided to liquidate the fund. Although the existing rights are serviced by the same insurance firm, new rights are accrued at a different industry-wide fund (PGB) (Bpf Kunststof- en Rubberindustrie, 2015).

The fourth case concerns the merger of two company pension funds of KPN. The pension fund Opf $\mathrm{KPN}$, the fund that services those employees who are not covered by the collective labour agreement, is liquidated and merged with PF KPN. The main reasons for the merger are simplicity of the pension scheme and lower costs for fund members. As the two pension funds were very similar to begin with, the main effect for the members is the lower operating costs (KPN Pensioen, 2015).

After ending its operations in the Netherlands, RBS chose to transfer its pension rights to the relatively new vehicle of a general pension fund ("Algemeen Pensioen Fonds"). A general pension fund allows a pension fund to run multiple pension plans, which can, or cannot, be separated from each other (ring fencing). As all members became inactive after their dismissal by RBS, the pension fund went into runoff. The prospect of a decreasing membership and higher costs per member put the generous nature of the pension plan into jeopardy. Therefore, the rights were transferred to a general pension fund, which can operate multiple pension plans, thereby benefiting from economies of scale while also keeping the generous nature of the pension plan intact (RBS NL Pension fund, 2015).

In the final case, after separating the banking activities (ING) and the insurance activities (NN) of ING, the decision was made to discontinue the current pension fund (Pensioenfonds ING) as of January 1, 2014, and create two new pension funds (ING CDC Pensioenfonds and NN CDC Pensioenfonds) to match the pension funds with the new companies. Another reason was for the employer to remove the company 
from the responsibility for the financial position of the pension plan, which due to recent regulations forced the employer to report a liability in its own accounts. As a compensation, ING paid a one-off contribution to the old pension fund now in runoff. Although these changes increased the probability of a pension cut in the future, they also improved the financial position of the fund in the short run (ING Pensioenfonds, 2015).

Table 2 gives an overview of the six cases, including relevant pension fund properties. The table presents the type of pension vehicle both before and after the discontinuity event. The reasons given for discontinuation can be classified into six categories, all of which fall within the external category: (a) A declining number of realized or anticipated members, (b) the prospect of lower costs per member after discontinuation, (c) regulatory pressure, including restrictions on the asset allocation and increasing difficulties to find board members, (d) an improved anticipated security of pension benefits, (e) improved simplicity of the pension plan (i.e., diminishing the amount of overhead) and (f) external pressure from the sponsoring company. In addition, the anticipated effect of discontinuity for the short and long term and for different types of members is presented, along with some summary statistics. 


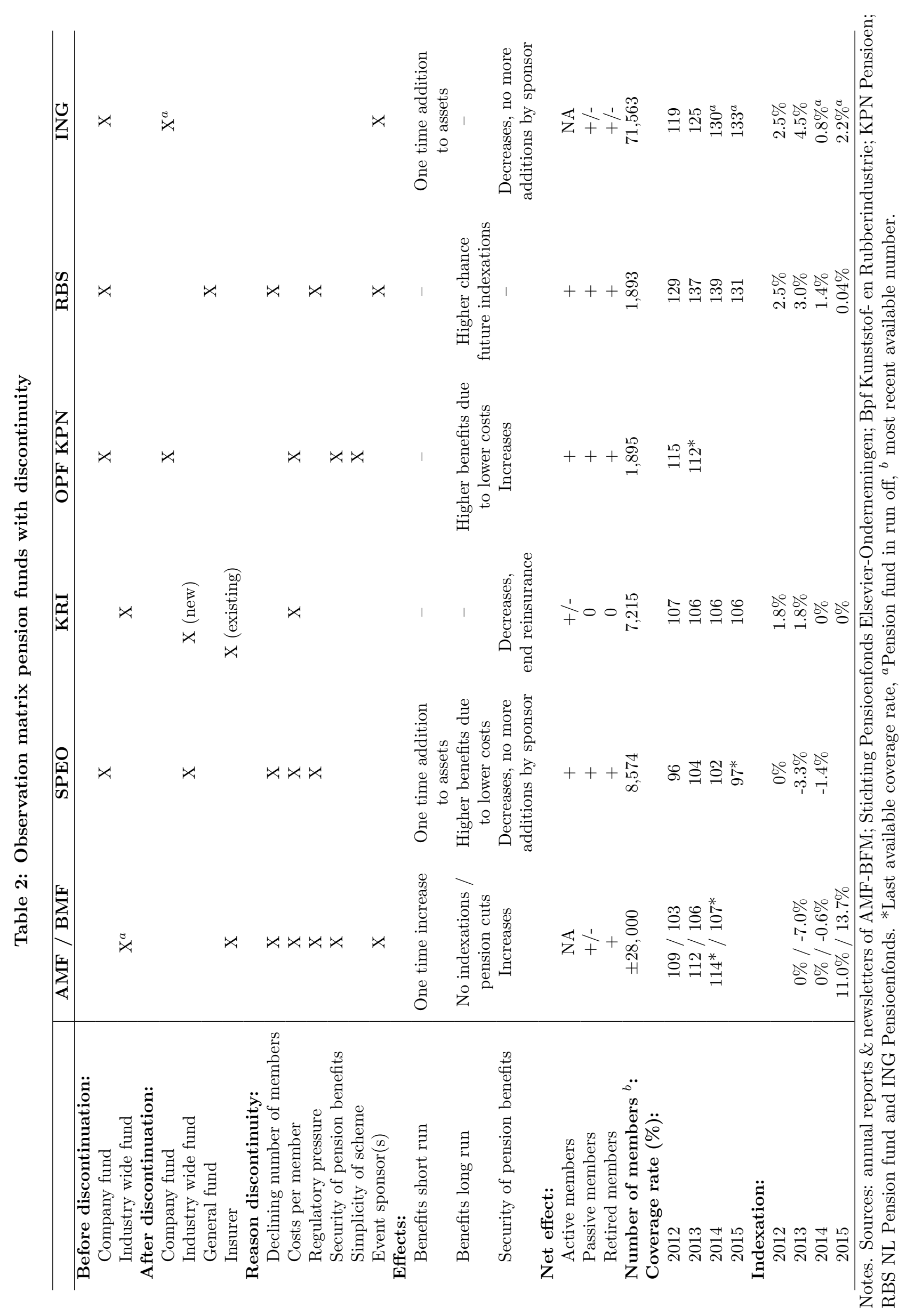


The six cases represent pension funds in the single institutional setting of the Netherlands. In this setting pension fund participation is quasi-mandatory, as pension fund members are not allowed to leave the pension fund. Discontinuity events were not triggered by financial problems in any of the cases, although in many cases the reasons associated with preventing future financial problems are reported. In most cases costs, often associated with low or decreasing membership, are reported as one of the reasons for liquidating the pension fund. Also, the effect of increasing regulatory pressure is often cited as a reason to discontinue, including a decreasing availability of competent and suitable (i.e., "fit and proper") board members, and the risk for the sponsor of being confronted with large deficits of the company pension fund. These case studies suggest that pension funds discontinue for a variety of reasons such as declining membership, the prospect of lower average costs and regulatory pressure. These reasons originate from external pressures, and to address them pension funds are discontinued. Although both the starting and the end situation differ between pension funds, not one of the discussed pension funds discontinuity events was unilaterally bad for the pension fund members. In some cases, all members benefited by lower costs and reduced complexity, while in other cases, the effect depended on whether the status of the member was active, inactive, or retired. Improving the prospect of pension fund members was often stated as one of the primary reasons motivating discontinuity, although this can also represent the effort of pension plan boards to pressure members to leave. Depending on the situation at hand, the discontinuity event has advantages and disadvantages for different types of members (i.e., active, passive or retired). In the cases discussed, the prospect of discontinuity should therefore not, on its own, put pressure on members to leave the pension fund, assuming they were allowed to. However, the dynamics discussed in these cases may depend on the institutional setting of the pension fund. In the following sections, we will describe and apply a simulation model to assess the discontinuity risk and the effect of the institutional setting on the discontinuity risk.

\section{Simulation study}

The case studies showed that discontinuity does not necessarily negatively affect pension fund members. However, the effects of pension fund discontinuity are likely to depend on the institutional setting of the pension fund. Therefore, we apply a simulation model in which we can account for institutional factors to analyse the occurrence and impact of pension fund discontinuity events. The simulation model is built on the asset return model of Koijen et al. (2010), using parameter estimates of Draper (2014) ${ }^{2}$. The asset returns, interest rates, and inflation that follow from this are used to simultaneously simulate a collective pension plan and an individual pension plan, so that the benefits from the collective plan can

\footnotetext{
${ }^{2}$ Asset returns are simulated using the Tilburg Finance Tool, which can be found via the following URL: https://drive.google.com/file/d/0B50YmOQ9iDtbdWdVYUpWVlFueFU/view?usp=sharing
} 
be compared with the pension benefit that would follow from an individual account.

For the sake of parsimony we abstracted from country-specific designs of pension plans and created both collective and individual pension plans that are not dependent on specific, or local, regulations. Also, for the simulated population, we tried to keep the model as simple as possible in order to keep all the relevant mechanisms visible. In Section 5.4, we present the most relevant sensitivity analyses, which describe various institutional settings.

\subsection{Population}

The simulated population of pension fund members consists of 10,000 individuals that become members of the pension fund at a randomly estimated year during the simulation. Members join the fund between the ages of 20 and 60 and are active members for a period of one to 47 years. When members become inactive (e.g., retire or find a job with a company that has a different pension fund), they continue as a passive member. Members cannot transfer their pension accumulation to another provider. The retirement age is fixed at 67 and the members pass away at random ages between 80 and 90 . Given these assumptions, the pension fund has on average 1,050 members during the simulation. All members have a fixed, inflation-corrected income of $\$ 30.000$, replacement rates (representing 40 years of membership) are adjusted for the period that the members are active in the pension fund.

\subsection{Collective pension plan}

The collective plan takes the form of a collective-defined contribution plan. This means that the sponsor (employer) does not share the investment risk with the pension fund, but that members share the risk among themselves (both intra- and intergenerational).

Members receive an inflation-corrected retirement entitlement of $2 \%$ of average income for each year that they are members of the pension fund. The contribution is progressive and is based on the actuarial value of the new entitlements. The relation between contribution / accumulation and age varies across countries and pension schemes. We choose contributions that are progressive with age as this is most common and because this matches the value of contributions to the value of entitlements, giving no redistributions between age groups. Section 5.4 shows a sensitivity analysis of this choice, by showing the implications of choosing a constant contribution instead of a progressive contribution. When the coverage rate is below $85 \%$ (i.e., $15 \%$ deficit), pension entitlements are lowered. In this case, entitlements are lowered by the deficit, divided over 10 years (e.g., a coverage rate of $80 \%$ means that entitlements are lowered with $2 \%$, this continues until the coverage rate exceeds $85 \%$ ). The same mechanism applies to coverage 
rates of over $115 \%$ (i.e., $15 \%$ surplus), entitlements are in this case increased by the surplus divided over 10 years. Coverage rates between $85 \%$ and $115 \%$ imply that there are no increases or decreases in the entitlements, except indexation ${ }^{3}$. Pension capital is invested for $40 \%$ in equity and for $60 \%$ in fixed income over the entire lifespan ${ }^{4}$, with a duration of 16 years. Costs are equal to $\$ 10$ per member and $0.3 \%$ of assets (based on Alserda et al. (2017)). Contributions and asset returns are added to pension capital (i.e., total assets) while costs and benefits are deducted. Total liabilities consist of the accumulated benefits discounted with the expected investment return $(3.27 \%+\text { inflation })^{5}$, taking the expected years in retirement for the different age groups into account. Section 5.4 presents the results of alternative specifications, including discounting with the long-term, 30 year real interest rate. The coverage rate is equal to total assets divided by total liabilities; as the real interest rate is used in the calculation of liabilities, this coverage rate represents the real coverage rate. After retirement age and pension cuts and indexations are calculated, members receive an income equal to their accumulated benefits; however, this can change from year to year in line with the plan's indexation policy.

\subsection{Individual pension plan}

In the individual pension plan, members contribute the same progressive premium to their individual pension account. During working life, the contributions-together with individual asset returns (using the same asset allocation)-are added to the pension capital, while costs, which are the same as for collective plans, are deducted. If pension members become inactive, their contributions stop, but asset returns and costs remain relevant for their pension capital. At retirement age, the pension capital is converted to an annuity, based on the expected return ${ }^{6}$ (using the annuity formula and the general expected life expectancy at retirement age).

\subsection{Time path}

Pension plan members join the pension fund in year 1. This implies that the number of members accrues gradually during the first years. As there are only a few members and no retirees, the coverage rate, and therefore indexation policy, will be relatively volatile during these first years. This effect evens out while the pension fund reaches a state in which the number of members joining the fund is approximately equal to the number of members leaving the pension fund by passing away. We start measuring performance indices (i.e., replacement rates, coverage rates, volatility of retirement entitlements, and indexation) from the start, but differentiate between the start-up phase (approximately 100 years) and the stationary

\footnotetext{
${ }^{3}$ Real pension cuts that are smaller than the inflation can be considered as partial indexation of nominal pensions.

${ }^{4} \mathrm{~A}$ common asset allocation in the Netherlands (Alserda et al., 2016)

${ }^{5}$ Which follows from Draper (2014); this return is neutral for the different generations in the sample.

${ }^{6}$ In Section 5.4.2, we analyse the sensitivity of using the actual long-term interest rate
} 
phase. At year 180, we simulate an external discontinuity event (no correlation with membership support or the coverage rate); at this time, all active members become inactive and no new members will join the fund. Although we described four different causes for a discontinuity event (internal or external, and social or financial), the result is the same: The pension fund goes into run-off, and therefore we model a single discontinuity event. At this event, all active members become inactive, and no new members join the fund. During the next few decades, the number of members slowly decreases as members pass away without new members entering. This holds for both the individual and the collective plan. Years 100-250 will be used to analyse the effect of the discontinuity event.

\subsection{Output}

A number of performance indices are used in order to analyse the effect of a discontinuity event. The most important indices are the replacement rate, calculated as the retirement income divided by the final income and adjusted for a 40-year working period; the development of the coverage rate; the volatility of retirement entitlements; and indexations.

\section{Results}

\subsection{Development}

Before we analyse the discontinuity events, we first discuss the development of the collective pension plan and the individual pension plan in our simulations. Figure 1 shows the median, $5 \%$ and $95 \%$ percentiles for both replacement rates (left axis) following from the collective pension plan and the individual pension plan, next to the median coverage rate of the collective plan (right axis). The development of the replacement rates shows a clear distinction between the first 100 years (start-up) and the next 80 years.

In the first period, any excess returns are used to create a buffer. This leads to lower benefits, as part of the contribution is directed to the buffer instead of directly to benefits (such as in the individual plan). However, as the coverage rate is close to $100 \%$, returns that are below expectations can still be partly offset by allowing for deficits. Therefore, volatility of the collective plan in the start-up phase is lower than that for the individual plan.

After the start-up period, most simulations show moderate buffers, and these pension funds give pension rights that are close to the planned benefit entitlement of $80 \%$ (40 years of $2 \%$ ). The returns that these buffers yield lead to a higher median replacement rate for the collective plan compared with the individual 
plan. However, some simulations have accumulated substantial deficits, resulting in significant pension cuts and reducing the $5 \%$ percentile of the collective plan below that of the individual plan. The opposite occurs at the upside of the distribution. These pension funds have accumulated positive buffers, yielding higher returns and allowing for increases in entitlements due to profit sharing. We can conclude that collective pension plans give higher benefits in the long run, but this is at the cost of lower benefits in the start-up phase and higher long-run volatility. This latter result is surprising, as collective plans, due to intergenerational risk sharing, are normally expected to yield lower risk, given the expected return. However, as the results illustrate, the possibility of joining a pension fund with a deficit, and the expected pension cuts that are associated with this, increases the downside risk of the collective plan beyond that of the individual plan. After the start-up phase, the collective plan gives substantially higher expected retirement incomes. By changing the asset allocation or by using financial hedge instruments, part of this higher result can be used to lower volatility at the cost of lower (expected) return. This way, the general finding of higher risk-adjusted returns of collective pension plans can remain intact. In this paper, we leave these options outside the scope of our analysis.

Figure 1: The development of replacement rates

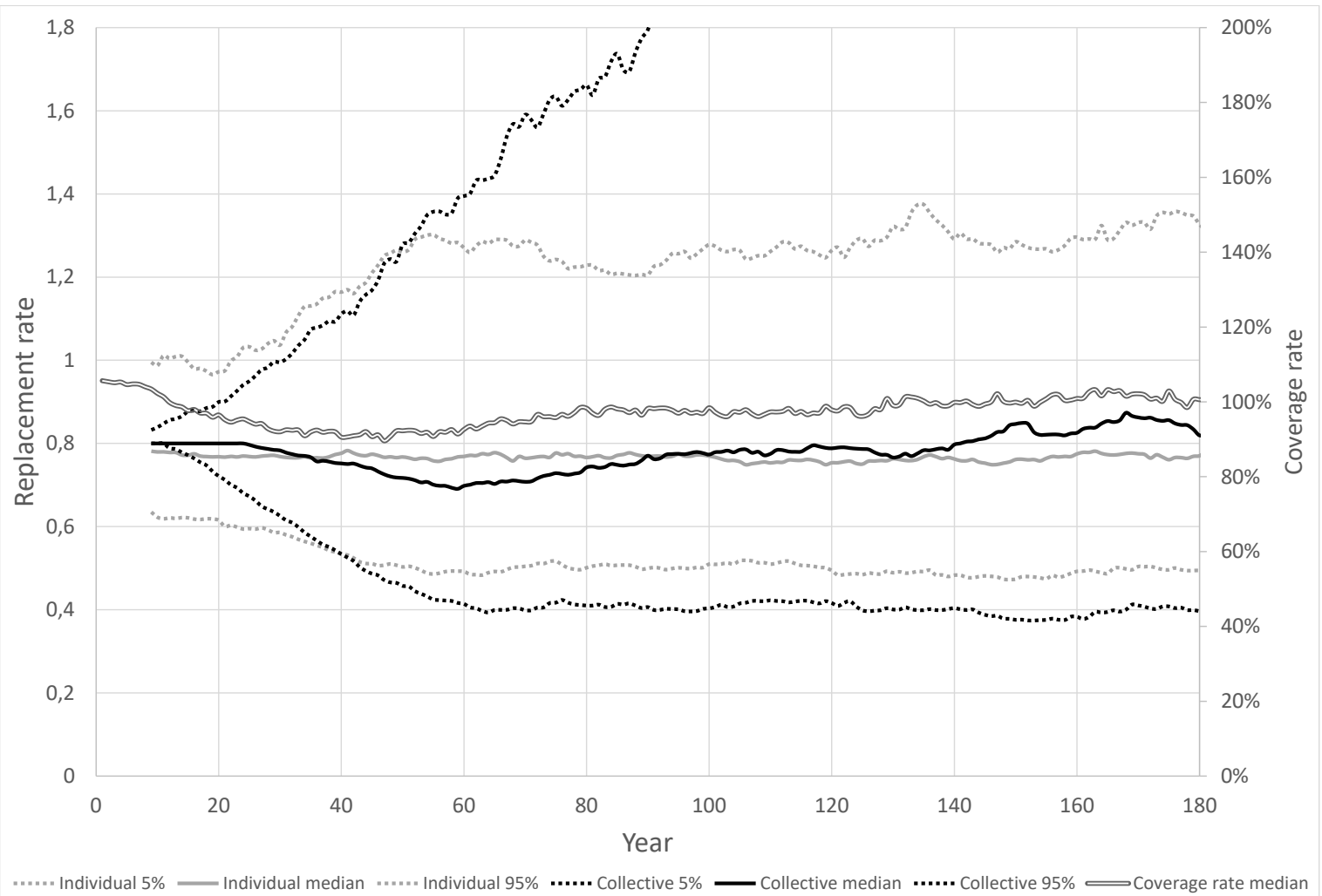

Notes. Development of replacement rates (left axis) from an individual and a collective plan and the median coverage rate of the collective plan (right axis). The replacement rates of the individual plan tend to exceed those of the collective plan for the first 90-100 years as the buffer is accrued, after which the collective plan tends to give the higher replacement rates due to average positive buffer. 


\subsection{Occurrence of discontinuity events}

There is a statistically significant relation between the coverage rate in year $t$ and the replacement rate in year $t+N$ within our period of analysis (years 100-180). This implies that the expected coverage rate at retirement can, with different degrees of precision, be calculated making use of the present coverage rate. In our model, the explanatory power of the coverage rate is the largest in the 12-13 years before retirement $\left(R^{2}=70.1 \%\right)$. Shorter periods have less explanatory power because the pension cuts / increases have not fully set in, due to their gradual application, while for longer periods other factors, such as asset returns, will diminish the explanatory power of the prediction.

Using a regression analysis, we can estimate the coverage rate at which the expected replacement rate of the collective pension plan is equal to that of the individual pension plan. The estimation of the minimum acceptable coverage rate depends on the time lag that we take for the coverage rate. Differences in time lags lead to different explanatory powers of the estimation, which changes the reliability of the estimation for the pension fund members. Lower reliability, and therefore higher uncertainty, will make the member less will to leave the fund, i.e., a higher minimum acceptable coverage rate. The magnitude of the coefficients of the coverage rate and the intercept, that also change with different time lags, also influence the minimum acceptable coverage rate. Figure 2 presents the relation between the lead (years to retirement) and the minimum expected coverage rate. For prospective and actual members who are within 20 years of retirement, the minimum acceptable coverage rate is between $93.1 \%$ and $94.1 \%$. For younger members further away from retirement, the minimum acceptable coverage rate is lower, down to $85.5 \%$ for the youngest members (20 years old). 
Figure 2: Minimum acceptable coverage rate

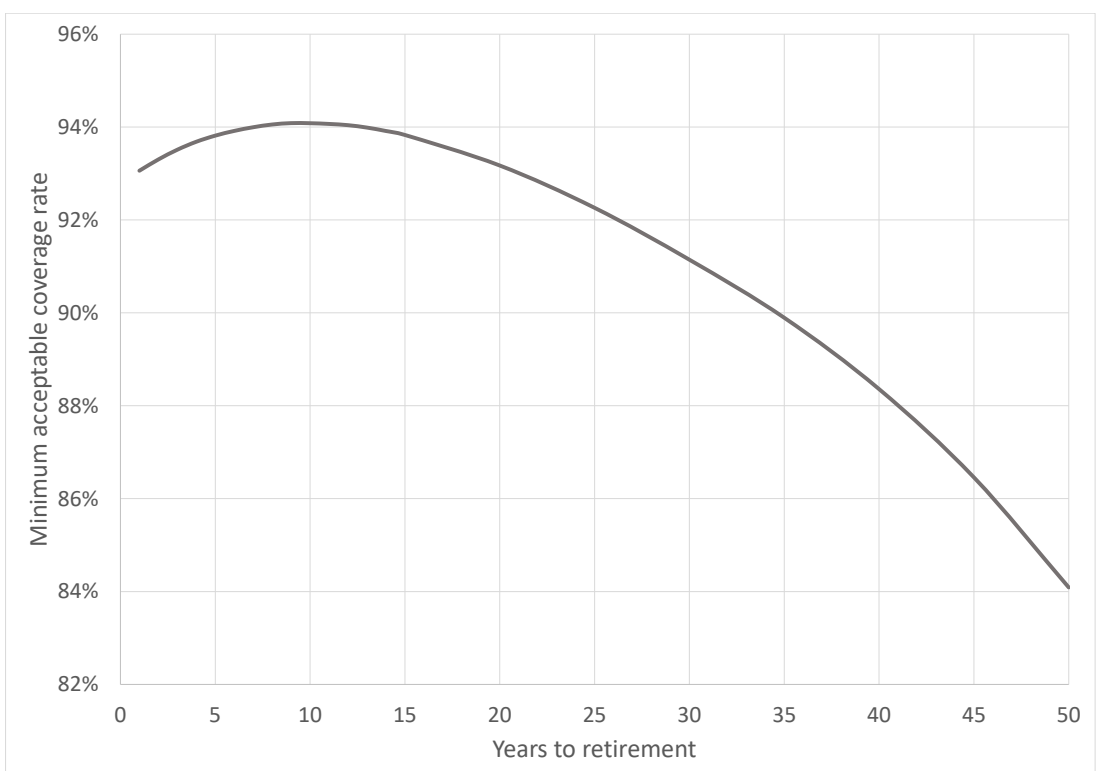

Notes. Relation between the years until retirement and the minimum acceptable coverage rate. The minimum acceptable coverage rate is the highest and most strict for 9-10 years before retirement $(94.1 \%)$ and decreases for both shorter and longer periods.

For the average pension fund member (45 years old, 22 years until retirement) the replacement rate can be estimated with this equation, which follows from the regression analysis:

$$
\text { Replacement rate }_{t+22}=-0.626+1.585 * \text { Coverage rate }_{t}
$$

Which is equal to the expectation of the replacement rate of the individual plan (average replacement rate is equal to $84.6 \%$ ) when the coverage rate is equal to $92.8 \%$. When the real coverage rate falls below 92.8\%, most pension fund members will no longer be willing to join, or continue membership in, the pension fund. When the coverage rate falls below $85.5 \%$, members will prefer an individual plan, wont be willing to be members of the pension fund, and the pension fund will be in runoff. We will use this minimum acceptable coverage rate as the point of discontinuity for a pension fund. When we instead use a power utility function ${ }^{7}$ with the average risk aversion $r=1.92$ (Alserda et al., 2016), we find a slightly higher average minimum acceptable coverage rate of 93.6\%. Incorporating variation in horizon and risk aversion will again give a lower coverage rate, at which point nobody is willing to join the pension fund. Another possible trigger for discontinuity is the replacement rate itself. Binswanger and Schunk (2012) finds that for the majority of members, the minimum replacement rate is above $70 \%$. Pension funds that have a replacement rate below $70 \%$ will therefore be considered insufficient, and members and employers might not be willing to pay the considerable premiums.

\footnotetext{
${ }^{7}$ equal to $U_{i}\left(P_{i}\right)=\frac{P_{i}^{1-r_{i}}}{1-r_{i}}$
} 
In our simulation model, we measure both triggers of internal discontinuity after the start-up period $(t=100)$. We find that in $87 \%$ of the simulations, after 80 years, the coverage rate drops below $85.5 \%$, resulting in the members preferring the individual plan over the collective plan. On the other hand, in $71 \%$ of simulations, the replacement rate falls below the acceptable minimum (70\%). In both cases, the triggers occur in our simulation on average once in 15 years. This shows that discontinuity events are relevant, as well as both of the triggers we describe. This illustrates the trade-off that occurs with stricter pension regulations. Stricter regulations will lead to more robust financial positions, but will sooner result in replacement rates that are below the acceptable minimum.

\subsection{Impact of discontinuity}

We have shown that discontinuity events occur, both in our simulation as in the cases discussed. We now focus on measuring the impact of discontinuity events. Figure 3 shows the development of the replacement rate for the collective pension plan, including a discontinuity event. The development for the first 180 years $(0 \geq N \geq 180)$ is equal to that of Figure 1 . However, in this case, after 180 years, the pension fund goes into runoff ${ }^{8}$, and no new contributions are collected (indicated by a dashed line). After approximately 245 years, all remaining members have died and no liabilities remain.

This figure shows that both the median (mean) replacement rate and its volatility increase after discontinuity. The median replacement is $101 \%$ at the point of discontinuity, implying a modest surplus of $1 \%$. Decreasing membership implies that the remaining members can increasingly benefit from this surplus, raising the median replacement rate. However, at the same time, in some simulations (49\%), the coverage rate is below $100 \%$ at the discontinuity event, implying a deficit. As membership declines, the absolute size of the deficit means that the relative impact for the members increases. In at least $5 \%$ of the simulations, assets are completely dissolved before all members have passed away. In these cases, some members will receive no retirement benefits at all. This figure also clearly shows that while median replacement rates rise, downside risk (indicated by the $5 \%$ percentile) also rises substantially. Therefore, we confirm that uncertainty of pension benefits increases when a discontinuity event occurs ${ }^{9}$.

For the individual plan, we find a small decrease in the median replacement rate, together with an increase in the volatility of the replacement rate, although it's more subtle than that of the collective plan. Both effects are due to the, on average, shorter contribution periods of the members and relatively higher costs relative to assets. Due to the discontinuity event, members in both plans stop contributing to the plan

\footnotetext{
${ }^{8}$ This can be interpreted as an external discontinuity event; there is no causal relation from the coverage rate to the discontinuity event

${ }^{9}$ Please note that in this situation the pension fund is in runoff with the coverage rate at year $t=180$. In the case of discontinuity events because of low coverage rates, the median replacement rate will drop and downside risk will increase even more
} 
earlier. As contributions have a dampening effect on the replacement rate ${ }^{10}$, shorter contribution periods lead to higher volatility of replacement rates.

Figure 3: Development of the replacement rates with a discontinuity event

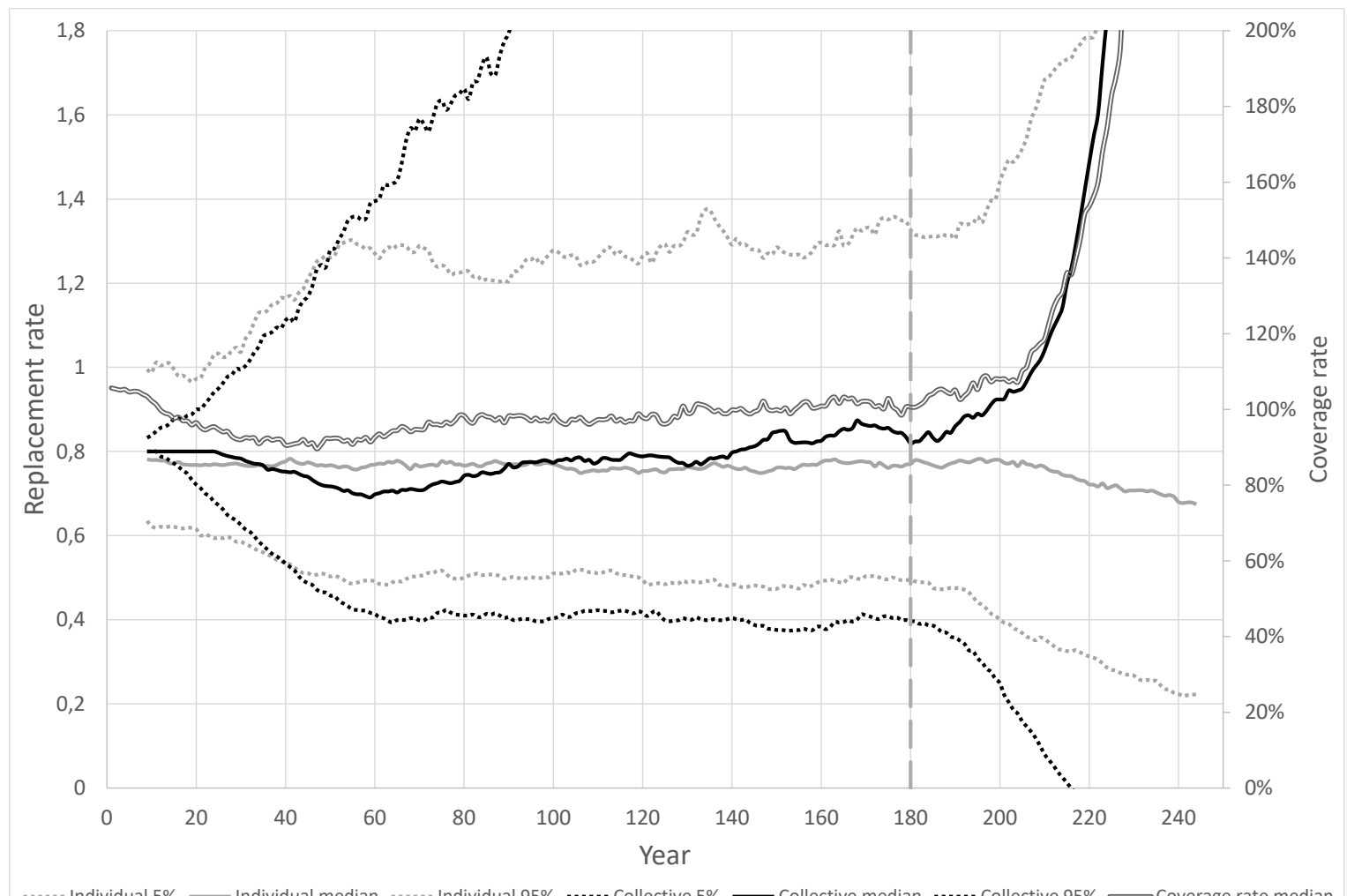

Notes. Development of replacement rates from an individual and a collective plan and the median coverage rate of the collective plan (right axis), including a discontinuity event at year $N=180$ (dashes). Replacement rates are more volatile after discontinuity.

Both the individual and collective plans are affected by the discontinuity event, but the collective plan is affected to a much larger degree, as the collective plan, in contrary to the individual plan, allows for deficits and surplus, which tend to be released at discontinuity. Median (and average) replacement rates rise substantially for the collective plan, but also become very risky. Especially in cases where the coverage rate is below $100 \%$, discontinuity events pose great risks for the members. The preference for an individual or collective plan in the presence of a discontinuity event, therefore, strongly depends on the risk preferences of the members. Risk-neutral or risk-seeking members will prefer the collective plan, while strongly risk-averse members will prefer the individual plan. Please note that the sponsor (employer) does not share investment risk in either the collective or the individual plan, collective plans with sponsors that do share risks (sponsor support) will have less volatile replacement rates (Van der Lecq and Van der Wurff, 2011).

\footnotetext{
${ }^{10}$ the actuarial fair contributions are equal to $100 \%$ of new entitlements, which forces the coverage rate in the direction of $100 \%$
} 
For example, in the last year before discontinuity $(N=179)$, without further information, we can say that an individual will be indifferent toward the collective and individual plan if that person has a risk aversion level of 2.68 (above average (Alserda et al., 2016)). As the collective plan has higher volatility, this individual will prefer the individual plan if he or she has higher values of risk aversion. After 20 years in discontinuity $(N=200)$, this value changes to 1.71 , which is below average, indicating that more members will prefer the individual plan. So, pension fund discontinuity decreases the group of members that are willing to participate in the collective fund, when they have the option to participate in the individual plan. In this respect, the possibility of a discontinuity event occurring, will make discontinuity more likely, as more members will choose to leave.

\subsection{Sensitivity of institutional factors}

So far, the simulation model has shown that discontinuity events are likely to occur. These events will improve expected replacement rates for the collective plan but also will strongly increase replacement rate volatility. In this section, we will analyse the occurrence and impact sensitivity of the discontinuity events on several important pension system characteristics of the pension system, and therefore of the important inputs to our model ${ }^{11}$. The findings of the sensitivity analyses are summarized in Table 3 .

Table 3: Sensitivity of pension fund discontinuity

\begin{tabular}{l|l|l}
\hline Setting & \multicolumn{1}{c}{ Occurrence } \\
\hline $\begin{array}{l}\text { Conservative discount } \\
\text { rate }\end{array}$ & $\begin{array}{l}\text { Coverage rate is lower, so } \\
\text { more pension cuts and possible } \\
\text { discontinuity events at starting } \\
\text { up period, afterwards, pension } \\
\text { cuts and discontinuity events } \\
\text { become less likely. }\end{array}$ & $\begin{array}{l}\text { Higher (implicit) buffer, so } \\
\text { discontinuity events have } \\
\text { mostly positive effects due } \\
\text { to the release of the buffer. }\end{array}$ \\
\hline $\begin{array}{l}\text { Constant contribution } \\
\text { with age }\end{array}$ & $\begin{array}{l}\text { No effect, conditional on } \\
\text { balanced population, }\end{array}$ & $\begin{array}{l}\text { No effect for collective, } \\
\text { younger members have paid } \\
\text { relatively too much. }\end{array}$ \\
\hline Fixed costs & $\begin{array}{l}\text { Average costs higher in starting } \\
\text {-up phase, therefore higher } \\
\text { probability of discontinuity } \\
\text { event. }\end{array}$ & $\begin{array}{l}\text { With reduction in the } \\
\text { number of members costs } \\
\text { increases and replacement } \\
\text { rates decline. }\end{array}$ \\
\hline Unbalanced population & $\begin{array}{l}\text { Volatility increases, so } \\
\text { discontinuity becomes more } \\
\text { likely. }\end{array}$ & $\begin{array}{l}\text { No effect, conditional on } \\
\text { actuarially fair contributions }\end{array}$ \\
\hline $\begin{array}{l}\text { Life expectancy shock } \\
\text { Discontinuity with } \\
\text { deficits }\end{array}$ & $\begin{array}{l}\text { Volatility increases, so } \\
\text { discontinuity more likely. }\end{array}$ & Replacement rates decrease. \\
\hline
\end{tabular}

\footnotetext{
${ }^{11}$ Varying the (starting) income, retirement age and age of death (larger interval) did not lead to significant changes in the outcome, expect for making the results less transparent. Therefore, these results are not presented in this paper.
} 


\subsubsection{Discount rate of liabilities}

Figure 4 shows the development of the replacement rate when collective liabilities are discounted with the 30-year risk-free interest rate instead of the expected asset return, which includes an equity premium. This discount rate is normally lower than the expected return; therefore, the present value of liabilities increases and the coverage rate decreases. Due to the lower coverage rate, the collective plan will, in this situation, have more pension cuts in the first years, leading to lower pension benefits (replacement rates), and finally to higher asset values. As asset returns tend to be higher than the discount rate, an implicit buffer is created. The return on this buffer increases the coverage rate, which leads to higher pension benefits.

So, the effect of using a conservative discount rate is that more pension cuts will be applied than necessary, as in a strong majority of the simulations coverage rates would increase also without pension cuts. This is especially the case for the first generations. Future generations benefit from this, as there will be more money available for them (i.e., the part of pensions that is cut, and the return on this), leading to higher pension benefits. This effect is clearly visible in Figure 4. Replacement rates tend to be lower in the first 80 years but are higher for the generations that retire in later years. The implicit buffer also decreases the downside risk of the collective plan, which disappears almost completely. The two types of buffers that are often available in this pension plan (coverage rate above 100\% (explicit buffer) and the coverage rate being conservative (implicit buffer)) imply that members tend to benefit from a discontinuity event that unlocks these buffers. This might even trigger members to force a discontinuity event when possible, as this would serve their interest.

This institutional factor, the conservative discount factor, makes discontinuity events less likely because reported solvency is lower, but the impact much smaller, as the actual solvency tends to increase due to more previous pension cuts. As the pension funds of the Netherlands case study face such discount factor, it may explain why discontinuity is not triggered internally, and why discontinuity tends to be either neutral or positive to the stakeholders. 
Figure 4: Replacement rates in the case of a risk-free discount rate

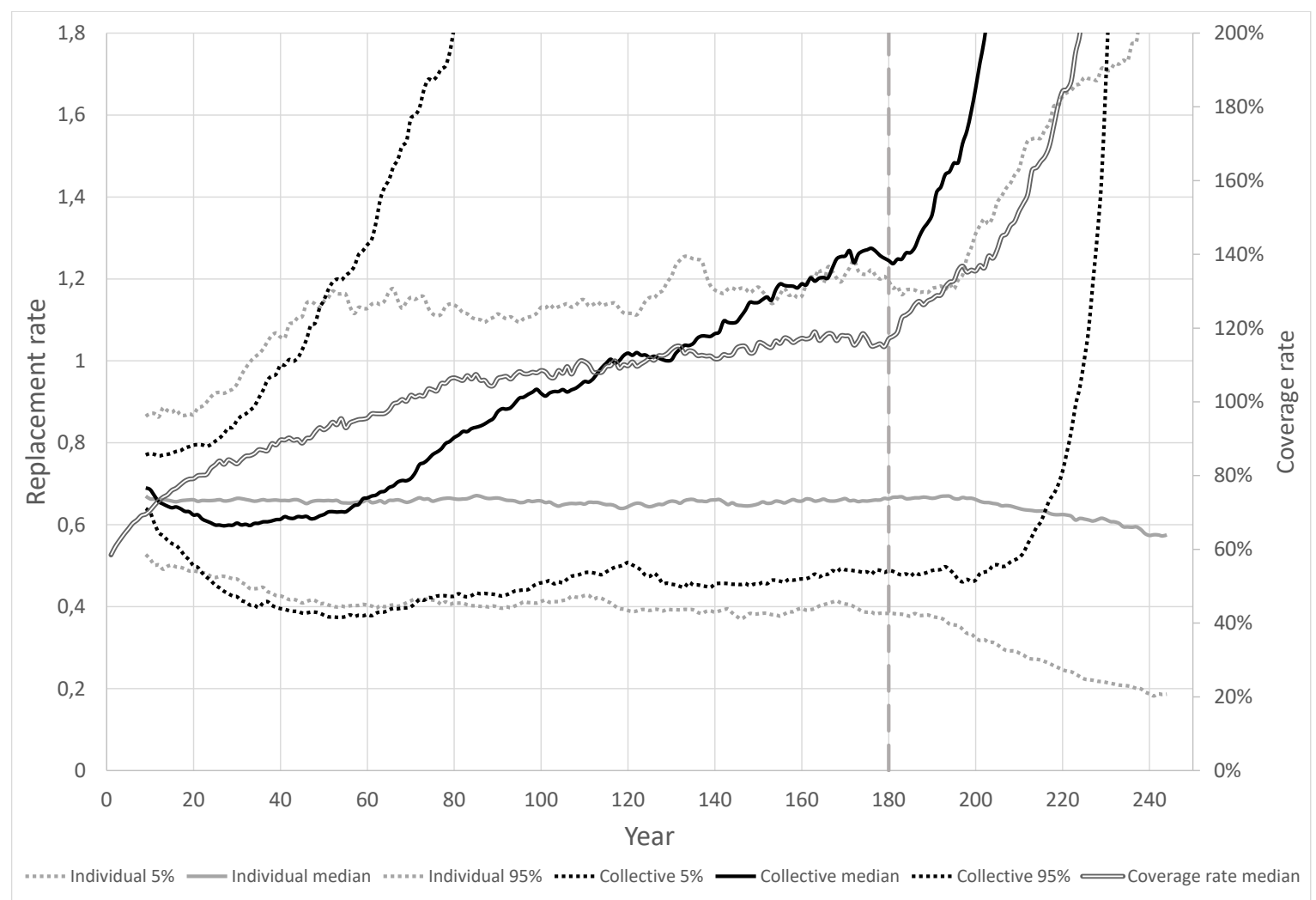

Notes. Development of replacement rates from an individual and a collective plan and the median coverage rate of the collective plan (right axis), including a discontinuity event at year $t=180$ (dashes) and with risk-free discounting and annuitization. Due to the lower discount value, the present value of liabilities increases, leading to more pension cuts and an implicit higher buffer. This in turn increases future pensions. As individual plan replacement rates drop, buying an annuity becomes more expensive.

\subsubsection{Interest rate individual annuities}

So far, the individual pension capitals where converted to an annuity using the expected return. This is a rather strong assumption, as pension providers in the market will not incorporate both the investment and longevity risk for free. In Figure 4, the replacement rates following from the individual plan, with annuities calculated with the risk-free, 30-year interest rate, are presented. As the risk-free interest rate is lower than the expected return, an annuity will become more expensive. Therefore, the replacement rates of the individual plan will shift downwards (including the 5\%, 50\% and $95 \%$ percentiles). In this case, the individual pension plan becomes more unfavourable as compared to the collective pension plan. Dependent on the specific setting (margin of pension providers), the replacement rate of the individual plan will be somewhere between these two possibilities. This implies that pension fund members, facing the trade-off between the collective and the individual plan, will determine their preferences to a large extent on the interest rate that is used for the annuitization of the capital in the individual plan. 


\subsubsection{Constant contribution with age}

Figure 5 shows the development of the replacement rate in the case of constant contributions, including a discontinuity event at year 180 . The fixed contribution is set at $15.2 \%^{12}$ of income, which is equal to the average contribution in our simulations.

Overall, the effect of the constant contribution is limited. The main effect for the collective plan is that the contribution is higher for the first years, because the average age of members is lower in this period; therefore, the contribution is higher (compared with progressive contributions). Due to the higher contributions in the first period, the coverage rate, and thereby the replacement rate, starts at a higher level and will approach the median path ( $80 \%$ of average income) sooner. Although the effect on the collective pension plan as a whole is limited, the effect on the members can be large, as there will be a shift of contributions from members who leave the fund early towards members who enter the fund later (Van der Lecq and Steenbeek, 2006).

The effects on the individual plan are greater ${ }^{13}$. As contributions are shifted towards earlier years, the actuarial value of contributions increases (higher contributions in first years have more time to accrue). Because of this, the value of retirement benefits increases, and now tends to exceed that of the collective plan. In the first period, when members retire who became member at an older age (as the pension fund didn't exist before), the replacement rate is lower. These members have made relatively lower contributions, resulting in lower benefits. After discontinuity, the opposite occurs, as more members retire who became inactive at younger ages due to a discontinuity event. Because of this, the effect of discontinuity turns around and becomes positive in the median in our simulations.

Having constant contributions instead of progressive contributions results in relatively minor changes for the collective plan. However, they yield significant changes for individual members who have not been members during their entire working life and for members of the individual pension plan.

\footnotetext{
${ }^{12}$ We do not take change in average age into account.

${ }^{13}$ Whether this is allowed again depends on the institutional setting of the pension plan.
} 
Figure 5: Replacement rates with constant contributions

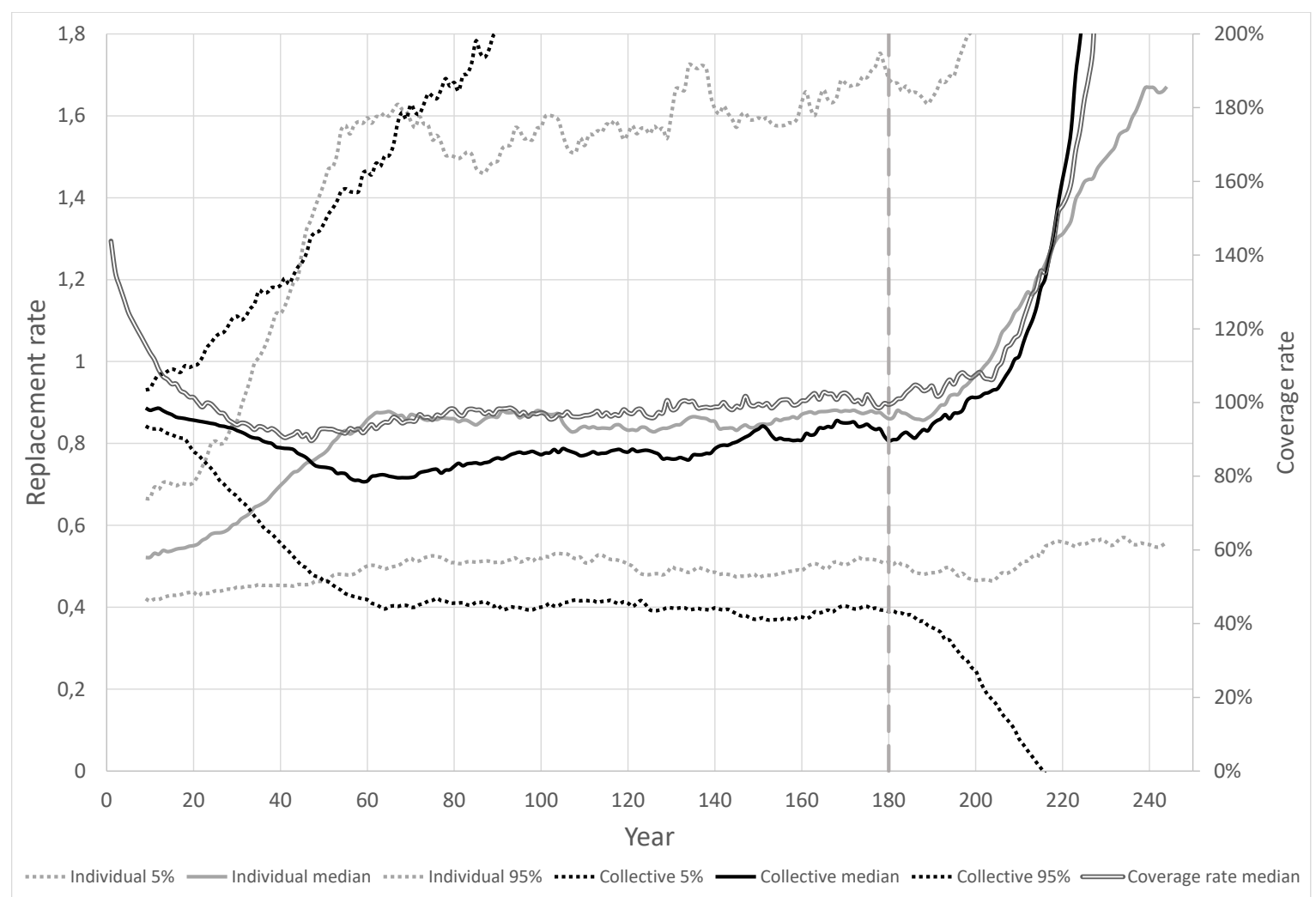

Notes. Development of replacement rates from an individual and a collective plan and the median coverage rate of the collective plan (right axis), including a discontinuity event at year $t=180$ (dashes) and with constant contributions. The effect on the collective plan is marginal, while the effect on the individual plan is large, in line with the members' ages at entry into and exit from the fund. The actuarial value of the individual plan increases as contributions are shifted to earlier ages (i.e., longer investment period).

\subsubsection{Fixed costs}

Figure 6 presents the development of replacement rates in the presence of fixed costs. For this model, half of the $\operatorname{costs}^{14}$ is assumed to be fixed, both for the collective and individual plan. In both plans, members are therefore dependent on total fund membership.

Average costs per member are higher in this model for the first and last years, when the number of members is lower than average. The years in between have more members, and therefore lower average costs due to economies of scale. Because of this, the coverage and replacement rates are lower in the startup period but thereafter exceed those of the baseline model, when the pension fund benefits from lower costs. In the case a pension fund goes in runoff due to a discontinuity event, total membership gradually decreases, as members die without new members joining the pension fund. With fewer members, costs

\footnotetext{
${ }^{14}$ Calculated as median costs for the years before the discontinuity event, which depend on the number of members and total assets under management.
} 
per member increase, and the last members present in the fund are confronted with very high costs, substantially lowering their pension benefits. However, the effects, in particular that of discontinuity, are relatively small for the collective plan, due to the presence of positive and negative buffers, which absorb some of the impact of changing average costs.

For the individual plan, the effect is more pronounced. With fixed costs, the impact of the discontinuity is far more severe. The entire distribution of replacement rates shifts downwards after discontinuity, as the remaining members have to incorporate an increasing share of the fixed costs. This makes discontinuity, particularly in the individual plan, a poor prospect.

\section{Figure 6: Replacement rates with fixed costs}

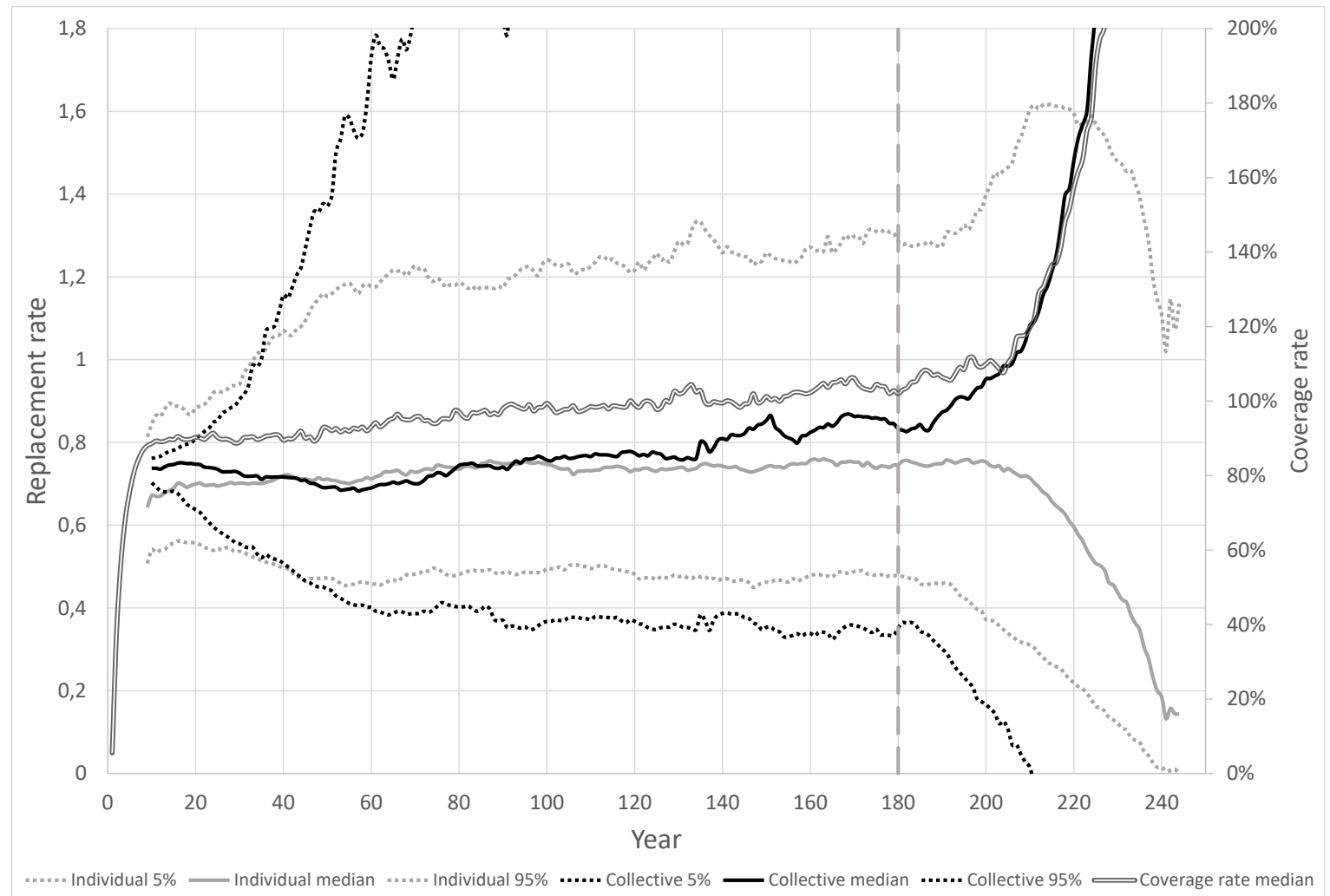

Notes. Development of replacement rates from an individual and a collective plan and the median coverage rate of the collective plan (right axis), including a discontinuity event at year $t=180$ (dashes) and with fixed costs. Effects are marginal for the first 180 years, but fixed costs increase the effects of discontinuity (more volatility). The effect is smaller for the collective fund, due to presence of financial buffers.

\subsubsection{Unbalanced population}

In many cases of discontinuity, all members become inactive at the same time. Alternatively, when no new members join the pension fund, the pension fund will eventually discontinue as well. This might 
happen when new members are no longer willing to join the fund (when participation is not mandatory); for example, due to the poor coverage rate. In this case, the population will shift towards older members, as the present members become older without new members joining the pension fund. Table 7 shows the development of replacement rates in this situation (at year $t=140$ ). The effect is very similar to that of the discontinuity event assumed thus far (instantly in runoff), but spread out over time. As relatively more members become inactive / retired, the volatility increases and median replacement rates increase.

Figure 7: Replacement rates with unbalanced population development

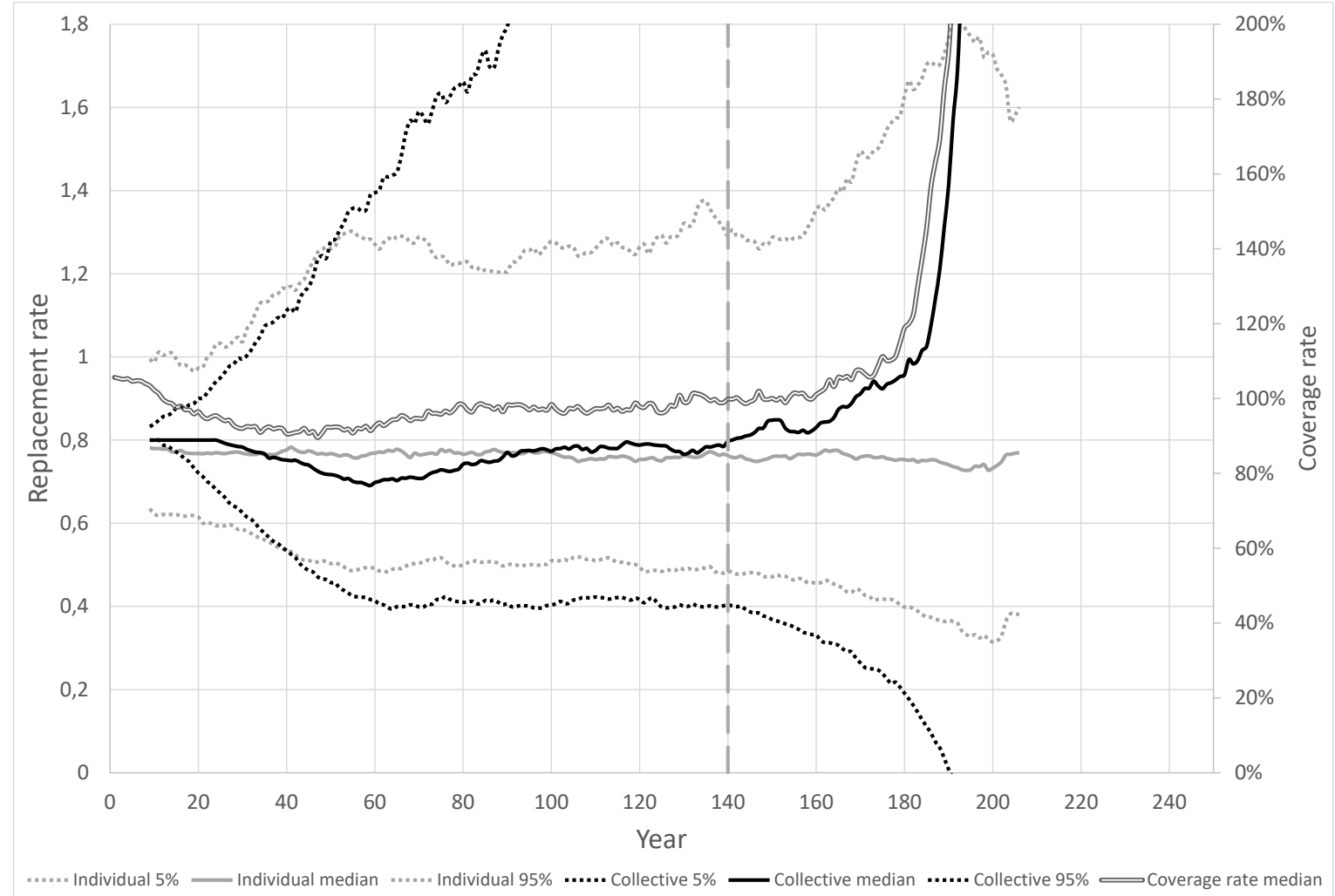

Notes. Development of replacement rates from an individual and a collective plan and the median coverage rate of the collective plan (right axis), including a alternative discontinuity event at year $t=140$ (dashes), at which point no new members join (but current members remain active). The effect of the discontinuity event is similar to the other discontinuity event, although the effect is more gradual.

\subsubsection{Life expectancy shock}

In Figure 8 the replacement rates are presented with an unexpected upward shock in life expectancy $(+2$ years) at year $t=100$. For the individual plan, the cost of the annuity increases, therefore decreasing the total distribution of replacement rates for new retirees (by 7.4\%). This effect is gradually visible after the unexpected life shock, as new members go into retirement (at which time the annuity is purchased).

Also, the replacement rates of the collective fund decrease. Due to the shock in life expectancy, liabilities 
increase, thus decreasing the coverage rate, which leads to lower benefits. Median replacement rates of the individual and collective plans become similar and the negative effect of a discontinuity event increases (lower buffers). As the life expectancy shock will normally be outside of the influence of the pension fund, and will affect all pension funds similarly, members are more likely to accept to negative consequences from this event.

Figure 8: Replacement rates with a life expectancy shock

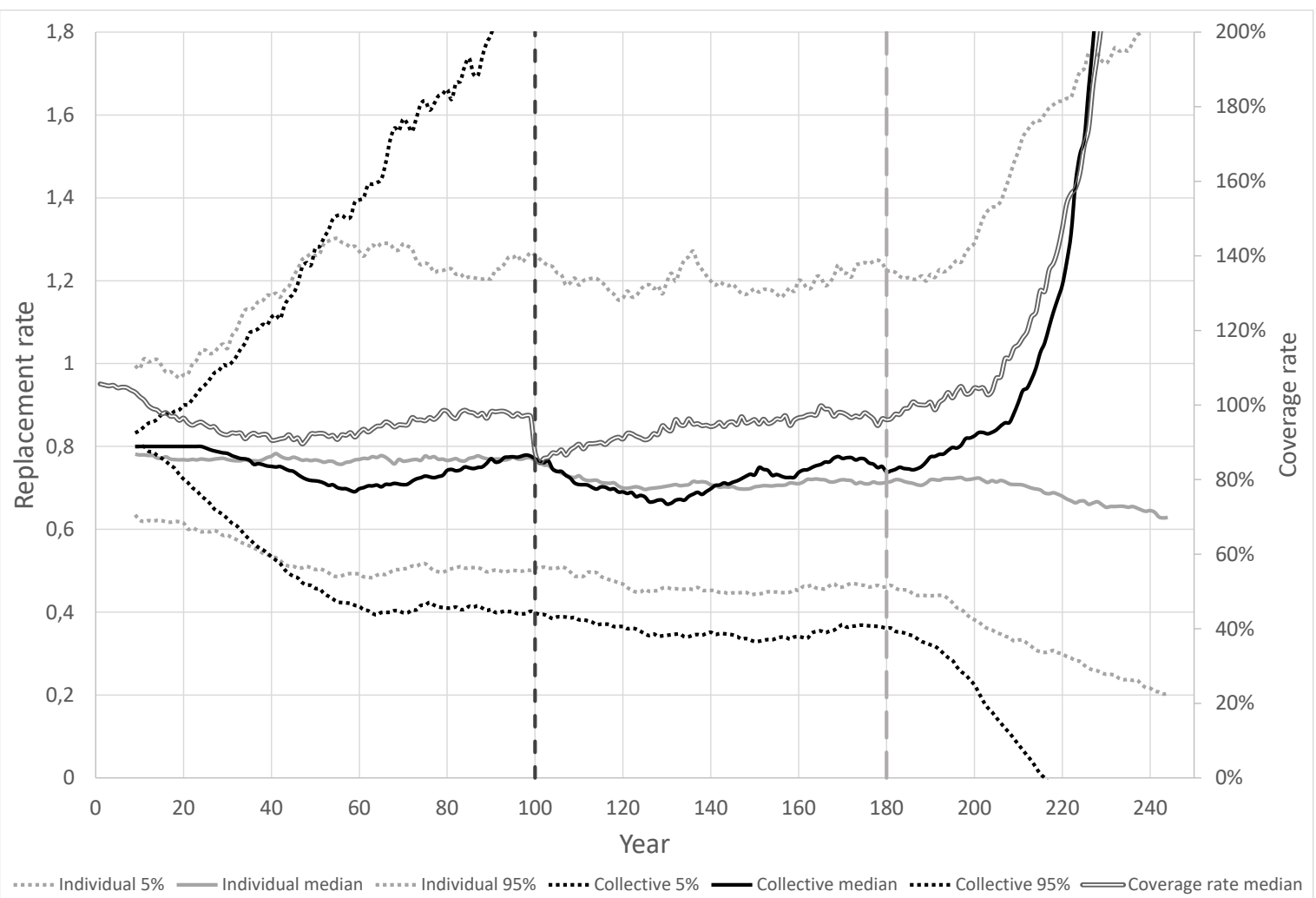

Notes. Development of replacement rates from an individual and a collective plan and the median coverage rate of the collective plan (right axis), including a discontinuity event at year $t=180$ (dashes) and a life expectancy shock ( +2 years) at year $(t=100$ (smaller dashes). Both replacement rates decrease due to the life expectancy shock, and the impact of discontinuity increases through greater volatility.

\subsubsection{Discontinuity with deficits}

So far, we have assumed that the discontinuity event was not related to the financial position of the pension fund (e.g., external trigger). However, as we have shown in Section 5.2, discontinuity events can also be triggered by the coverage rate, and in these cases there is a strong correlation between the coverage rate and the discontinuity event. In Figure 9, we present the development of the replacement rates with a discontinuity event (year $t=180$ ) at which point the coverage rate drops to $85.5 \%$ (as found in Section 5.2). This implies that in the year of discontinuity, pension benefits are instantly cut by 
approximately $1.45 \%((100-85.5) / 10)$. We do not simulate financial problems for the individual plan, as by definition, these have $100 \%$ solvency.

With a financial shock, the replacement rates substantially shift downwards after the discontinuity event. In this case, after the discontinuity event, the median replacement rate decreases rather than increases. The $5 \%$ percentile stays relatively stable as these funds were already in financial difficulties. Despite the fact that the replacement rates tend to decrease after the discontinuity event, approximately 30 years after discontinuity they start increasing again. At this time, the buffers are restored, due to various pension cuts, and the continuing members can increasingly benefit from the remaining buffer (in the median path). Discontinuity events that are related to financial problems lead to lower replacement rates and higher volatility than discontinuity events that are uncorrelated to the financial position of the fund.

Figure 9: Replacement rates with solvency problems.

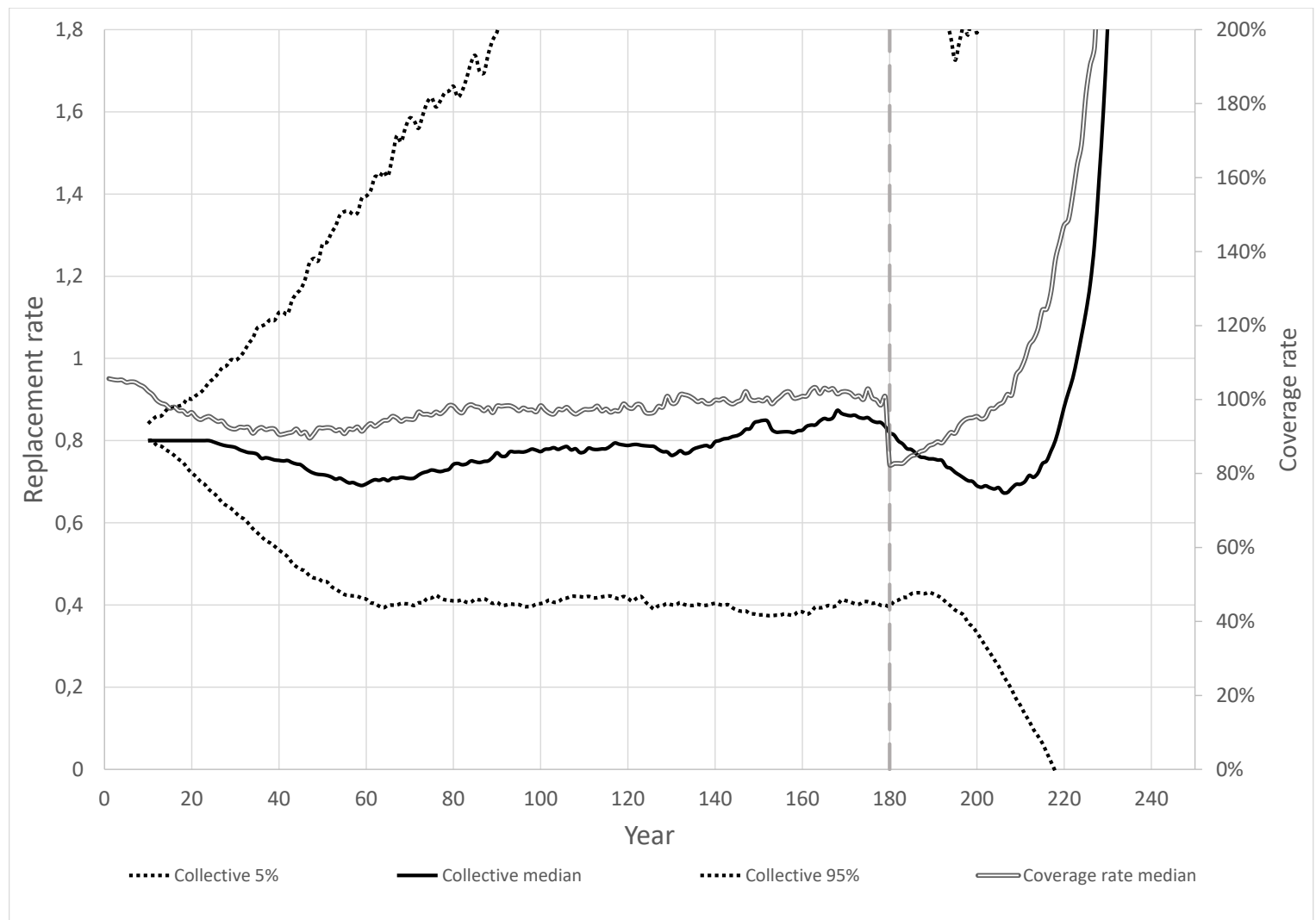

Notes. Development of replacement rates and the median coverage rate (right axis) from a collective plan, including a discontinuity event at year $t=180$ (dashes) at which the coverage rate changes to $85.5 \%$. This decreases replacement rates in the short run, but for the last members the presence of financial buffers offsets this effect. 


\section{Conclusion}

This paper analyses the occurrence and impact of discontinuity events of collective pension funds. Pension funds are often implicitly assumed to have an infinite lifetime, while in practice that European pension funds discontinue. Furthermore, discontinuity events are often described as bad events for the actors involved, but research on the impact of discontinuity events is absent. In addition, discontinuity events may be strongly linked to the institutional setting; but this relation has not been studied before.

This paper intends to fill these gaps. Using a case study combined with a simulation model, we assess the occurrence and impact of pension fund discontinuity and the impact of the institutional setting.

We differentiate between four types of discontinuity event triggers. Internal triggers, in contrast to external triggers, originate from within the pension fund itself. These include a lack of trust in the fund and low replacement rates. The prime external trigger is the discontinuation of the sponsoring employer (e.g., bankruptcy). Another distinction is between social and financial triggers. Social triggers originate from the members; lack of support can make them unwilling to participate in the pension fund. Financial triggers, like solvency problems, can also force a pension fund into discontinuation. In this case, the sponsoring company or financial supervisors are more likely to trigger a discontinuity event. These triggers are closely connected. Financial problems, for example, can make members uncertain about their future benefits, thus lowering trust, while external financial shocks can force internal financial problems. The result, however, is the same: The pension fund goes into runoff, all active members become inactive, and no new members will join the pension fund. The trigger of the discontinuity event is therefore of lesser importance, although the correlation with the coverage rate (Section 5.4.7) does influence the impact of the discontinuity event.

The analysis of six pension funds that discontinued shows there is much variation in the start-up situation, motivation, and continuation choices surrounding pension fund discontinuity. However, discontinuity is not unilaterally bad for the stakeholders involved, including pension fund members of the collective pension plans. Most of the cases discussed even showed significant improvements for all the members. In all cases, discontinuity was caused by an external event outside of the influence of the pension fund. However, the cases discussed represent pension fund discontinuity in the institutional setting of the Netherlands, other institutional settings may better allow for internal discontinuity events. Using a simulation model, we analyse the impact of the institutional setting on pension fund discontinuity.

The results of a long term (250 year) stylized pension fund simulation model shows that internal discontinuity events are likely to occur within the horizon of our simulations, with discontinuity events occurring more often due to lack of membership support than financial problems, although both are strongly connected. However, in line with the results of the case study, our model shows that discontinuity is not 
necessarily bad for pension fund members. The riskiness of the replacement rate tends to increase after a discontinuity event, but the same is true for the median replacement rate. Whether a discontinuity event is considered bad for a member, therefore, depends on his/her risk aversion and on the institutional setting of his/her pension fund. This poses a trade-off in the design of the pension system. Institutional factors influence both the perceived and actual financial position of the pension fund, but not necessarily to the same extend or in the same direction. Stricter regulations for example, increase the financial stability of the pension fund, but lower the perceived position of the fund. This makes discontinuity more likely, as the perceived financial position is lower, and members and sponsors will be sooner inclined to discontinue the pension fund, but reduces the impact of discontinuity, because the actual financial position will normally increase (e.g., due to higher pension cuts in the past).

Sensitivity analyses show that when pensions use conservative discount rates, the impact of discontinuity events improves due to higher (implicit) buffers. The presence of fixed costs deteriorates the effect of discontinuity due to higher average costs when the number of members decline. A population that is either unbalanced, or which faces a rise in life expectancy, results in more volatile pension benefits and higher occurrence of discontinuity events. Constant contributions, as opposed to progressive contributions, have redistributive effects within the population but do not significantly alter discontinuity risk.

The replacement rate of the collective plan tends to surpass that of the individual plan, although the latter is in most cases less volatile. The on average positive buffer (i.e., surplus) increases expected benefits for future retirees. However, the risk that the collective plan presents for a member to start in a situation with a deficit, increases downside risk. Of course, this can be corrected by adjusting the asset allocation; however, this falls outside the scope of this research. The individual pension plan is especially sensitive to the rules concerning the annuitization of pension capital at retirement age. If annuitization is mandatory and based on the risk-free interest rate, the collective pension plan is practically superior to the individual plan. The main advantages of the collective plan are the options of spreading defects and surpluses and the possibility of continuing to invest during retirement. 


\section{Discussion}

The analysis in this paper shows that discontinuity events are not necessarily bad to pension fund members but that their impact strongly depends on the specific setting of a discontinuity event. In this paper, we have used a case study and a stylized model to describe pension fund discontinuity. Including more of the real life complexity in the (mostly country- specific) model will change the exact impact of discontinuity. We will discuss some of these factors here.

For individual plans, we have assumed a single pension plan with a single asset allocation that does not change within our horizon. Individual plans may have particular value by allowing for customizing the plan to individual preferences and time to retirement (i.e., lifecycles). The value of the individual plan (compared with the collective plan) will therefore be more attractive than in our model (see, for example, Alserda et al. (2016)).

In our model, we constantly correct for inflation to deal with the long time horizon. Therefore, the results represent the purchasing power of pension fund members, which in our opinion will be most relevant for the members. However, many countries use nominal coverage rates and focus on nominal replacement rates. This may change pension fund behaviour (e.g., focusing less on inflation hedging).

As the analysis shows, we cannot assume that discontinuity events are either unilaterally bad or good for pension fund members. The analysis of six pension funds that have discontinued showed that the availability of continuation options may abate the impact of discontinuity risk. However, these six cases were active in the same institutional setting of the Netherlands), and results may be different for other institutional settings. The analysis of the impact of discontinuity events, following our discussion of the sensitivity of the institutional setting, should always be related to the specific setting of the pension system under scrutiny, taking institutional factors into account. 


\section{References}

Alserda, G. A. G., J. A. Bikker, and S. G. Van der Lecq (2017). X-efficiency and economies of scale in pension fund administration and investment. DNB Working Paper NO. 547 / March.

Alserda, G. A. G., B. G. C. Dellaert, L. Swinkels, and S. G. Van der Lecq (2016). Pension risk preferences. Netspar Industry Design Paper 62, Rotterdam.

AMF-BFM (2013-2016). Pensioenbulletin AMF-BFM $2013-2016 . \quad$ https://www . mijnwerkerspensioen.nl/documenten.

Beetsma, R. M. and L. Bovenberg (2009). Pensions and intergenerational risk-sharing in general equilibrium. Economica 76(302), 364-386.

Beetsma, R. M., W. E. Romp, and S. J. Vos (2012). Voluntary participation and intergenerational risk sharing in a funded pension system. European Economic Review 56(6), 1310-1324.

Bikker, J. A. and J. De Dreu (2009). Operating costs of pension funds: the impact of scale, governance, and plan design. Journal of Pension Economics E Finance 8(1), 63.

Binswanger, J. and D. Schunk (2012). What is an adequate standard of living during retirement? Journal of Pension Economics and Finance 11(02), 203-222.

Bonenkamp, J. and E. Westerhout (2014). Intergenerational risk sharing and endogenous labour supply within funded pension schemes. Economica 81 (323), 566-592.

Bovenberg, L., R. Koijen, T. Nijman, and C. Teulings (2007). Saving and investing over the life cycle and the role of collective pension funds. De Economist 155(4), 347-415.

Bovenberg, L. and R. Mehlkopf (2014). Optimal design of funded pension schemes. Annual Review of Economics 6, 445-474.

Bpf Kunststof- en Rubberindustrie (2011-2015). Jaarverslag BPF Kunststof- en Rubberindustrie 2011 2015. https://www.bpfkunststof-rubber.nl/jaarverslagen.

Brady, P. J. (2010). Measuring retirement resource adequacy. Journal of Pension Economics and Finance $9(02), 235-262$.

Chen, D. H., R. M. Beetsma, E. H. Ponds, and W. E. Romp (2016). Intergenerational risk-sharing through funded pensions and public debt. Journal of Pension Economics and Finance 15(02), 127-159. 
Cui, J., F. De Jong, and E. Ponds (2011). Intergenerational risk sharing within funded pension schemes. Journal of Pension Economics and Finance 10(01), 1-29.

Draper, N. (2014). A financial market model for the netherlands. Netspar Discussion Paper 3(070), $1-23$.

Frijns, J. (2010). Dutch pension funds: aging giants suffering from weak and inconsistent risk management. Rotman International Journal of Pension Management 3(2), 16-23.

Gollier, C. (2008). Intergenerational risk-sharing and risk-taking of a pension fund. Journal of Public Economics 92(5), 1463-1485.

ING Pensioenfonds (2012-2015). Jaarverslag Stichting ING Pensioenfonds 2012 - 2015. https://www . pensioenfondsing.nl/documenten/\#7306.

Koijen, R. S., T. E. Nijman, and B. J. Werker (2010). When can life cycle investors benefit from timevarying bond risk premia? Review of Financial Studies 23(2), 741-780.

KPN Pensioen (2011-2015). Jaarverslag KPN pensioen 2011 - 2015. https://www.kpnpensioen.nl/ jaarverslagen.

Molenaar, R., J. Peijnenburg, and E. Ponds (2011). Should i stay or should i go? break even funding ratios for db pension plan participants. NETSPAR Discussion Paper 4.

OECD (2015). Pension Markets in Focus, 2016 edition. Technical report, OECD Publishing, Paris.

Ponds, E. H. (2003). Pension funds and value-based generational accounting. Journal of Pension Economics and Finance 2(03), 295-325.

Ponds, E. H. and B. Van Riel (2009). Sharing risk: the Netherlands' new approach to pensions. Journal of Pension Economics and Finance 8(01), 91-105.

RBS NL Pension fund (2011-2015). Annual Report RBS NL Pension fund 2011 - 2015. https://www . rbsnlpensionfund.com/downloads/.

Stichting Pensioenfonds Elsevier-Ondernemingen (2011-2015). Jaarverslag SPEO 2011 - 2015. http: //www.speo.nl/30-jaarverslagen.html.

Teulings, C. N. and C. G. De Vries (2006). Generational accounting, solidarity and pension losses. de Economist 154(1), 63-83. 
Van der Lecq, S. G. and O. W. Steenbeek (2006). Kosten en baten van collectieve pensioensystemen. Kluwer.

Van der Lecq, S. G. and A. W. Van der Wurff (2011). The price of pension risks. The Journal of Risk 13(3), 83 .

Westerhout, E. (2011). Intergenerational risk sharing in time-consistent funded pension schemes. Netspar Discussion Paper. 